\title{
Recent Attacks on Judicial Independence: The Vulgar, the Systemic, and the Insidious
}

\author{
James E. Moliterno ${ }^{1 \star \star}$ and Peter Čuroš² (iD \\ ${ }^{1}$ Washington \& Lee University School of Law, Lexington, Virginia, United States and ${ }^{2}$ University of Oslo, Oslo, Norway \\ *Corresponding author: curos.peter@gmail.com
}

(Received 14 September 2021; accepted 20 September 2021)

\begin{abstract}
This article offers an opening to Central and Eastern Europe (CEE) situation and attacks against the judiciary in this region since 2010. The focus is not primarily on historical path dependence like the rest of this issue. Instead, the focus aims at the nature of attacks on the judiciary. Such attacks have appeared in CEE and the US in recent years. Its interest lies in explaining similar patterns visible in the judiciaries of CEE. Particularly, it looks at the current conditions in the Czech judiciary, political interventions in Poland since 2015 and in Hungary since 2010, and undermining of trust towards judiciary in the U.S., where attempts for delegitimizing the judiciary have happened since 2016. The article draws on similarities of attacks of authoritarian governments and responses of judiciaries. The authors highlight similarities and diversities of CEE countries 30 years after the fall of the communist regime and a path of these resemblances and varieties.
\end{abstract}

Keywords: Czech Republic; Hungary; Poland; the U.S.; attacks on the judiciary; judicial independence

\section{A. Introduction}

Attacks on judicial independence come in many forms. Some are vulgar, awkward, and often end as clumsy and ham-handed efforts. Others are systemic, undermining the legal structures designed to ensure independence. Still, others are insidious efforts designed to undermine the public trust underpinning an independent judiciary. This article will compare recent attacks of all three kinds and discuss their likelihood of success.

The vulgar efforts are direct interferences with particular judges in particular cases and issues. A state official, perhaps a minister, approaches a judge with a request/demand that the judge rule on a specific case as the government would wish the judge to rule. It could be, for example, to produce a political result that gives the government more power, or it could be a financial result favoring a state official or some friend of the official. The efforts also appear offensive, as the actor carrying out such an attack seems like he or she cannot gauge the situation. It is an attack that applies direct pressure to the recipient, with full knowledge of the immorality or illegality of the action. If the formal institutions are stable, such an attack seems more clumsy than dangerous. These attempts may produce the interferer's desired result but are unlikely to do severe, longlasting, or widespread damage to a country's judiciary. Counteracting a vulgar attack may even produce gains in judicial independence when the efforts become known to the public and spark

James E. Moliterno is Vincent Bradford Professor of Law, Washington \& Lee University School of Law.

Peter Čuroš works at the Institutt for Privatrett, Univeristetet i Oslo. He is member of the project "Judges under Stress The Breaking Point of Judicial Institutions Project." The project is financed by the FRIPRO program of the Norwegian Research Council and the University of Oslo (2019-2022). 
public outrage. Alternatively, if the country's democratic institutions are weak, the consequences of an isolated incident may produce serious harm.

The systemic attacks aim for a structural change that enables the government to control or heavily influence future judicial outcomes. Sometimes, such changes masquerade as legitimate judicial reform measures. Systemic attacks are effective at damaging judicial independence structures and, unless political change comes, can have long-lasting, devastating effects on judicial independence. Nevertheless, if the ruling party changes, as it often does in Central and Eastern Europe, the systemic damage can be undone and judicial independence restored.

The insidious efforts may be the most dangerous and have the most long-lasting effects. Every successful judiciary, and the country it serves, depends on public trust. If the insidious attacks succeed in undermining public trust in the judiciary, even political change may not put Humpty Dumpty back together again. These are attacks directed at the legitimacy of the judiciary. The political actors leading these attacks are first aiming their rhetoric towards the public, claiming that if the political actor's promises are not delivered, it is the fault of the judges who stand against any positive change. Meanwhile, the political actors seek to maximize their own power by diminishing the public confidence in the judiciary.

In recent years, efforts to attack and undermine judicial independence have been evident. Here we will briefly compare those efforts in Czech Republic, Slovakia, Poland, Hungary, and the U.S.

Section B starts with distinguishing between independence as a personal trait and a structural requirement, where the latter is in our focus. Moreover, the concepts of independence and accountability are explained following with the cases of incorrect application of accountability that constitutes an attack on the independence of the judiciary. Section $\mathrm{C}$ presents the first kind of attack - the vulgar, which ends clumsily or devastatingly. An example of such an attempt to intervene in the judiciary comes from the Czech Republic and Slovakia. Section D presents the second type of attack - the systemic, as when the parliamentary majority intervened in the judiciary in Hungary and Poland. Finally, section E presents the third kind of attack-the insidious, which is explained through the U.S. case.

\section{B. Judicial Independence and Accountability: Background}

Scholars and key state actors often disagree about the quintessential meaning and significance of judicial independence. ${ }^{1}$ Moreover, the concept is addressed in various versions. Judicial independence is perceivable, at least in two common connotations. In one version, independence is about a judge's inner conscience and a commitment to decide cases according to that inner heart-a guarantee of appropriate character and independence of mind. ${ }^{2}$ In the second, judicial independence is about structures that try to insulate judges from the influence of state actors-institutional mechanisms of control within the constitutional structure. This notion of judicial independence will be referred to as structural independence.

The first meaning is especially prominent in judicial codes of conduct. Definitions of independence explicitly rely on this idea of the individual judge's good conscience. ${ }^{3}$ By contrast, international documents like decisions of the Court of Justice of the European Union (CJEU) ${ }^{4}$,

\footnotetext{
${ }^{1}$ See Sanford Levinson, Identifying "Independence": The Role of the Judge in the Twenty-First Century, 86 B.U. L. REV. 1297 (2006).

${ }^{2}$ See John Ferejohn, Independent Judges, Dependent Judiciary: Explaining Judicial Independence, 72 S. CAL. L. REV. 353 (1999); Pamela S. Karlan, Two Concepts of Judicial Independence, 72 S. CAL. L. ReV. 535 (1998).

${ }^{3}$ For an international code of judicial ethics, see Bangalore Principles of Jud. Conduct of 2002, Nov. 25-26, 2002, U.N. Doc. E/CN.4/2003/65 Annex at para. 1.2 (Jan. 10, 2003). For national codes of judicial ethics, see Jud. Code of Conduct, The Jud. Council of the Slovak Republic (2015), https://www.sudnarada.gov.sk/data/files/697.pdf; Act of 27 July 2007, Law on Common Courts Organisation, J.L. 2001, No. 98, item 1080 (Poland), https://www.legislationline.org/download/id/6754/file/Poland_ Law_Common_Court_Organisation_2016_en.pdf.

${ }^{4}$ For a review of how the CJEU evaluates external independence, see Case C-64/16, Associação Sindical dos Juízes Portugueses, ECLI:EU:C:2018:117, para. 44 (Feb. 27, 2018) (Protecting the judicial branch from other branches of power and ensures the absence of any hierarchical constraint or subordination to any other body, from internal independence, which
} 
European Court of Human Rights (ECtHR), ${ }^{5}$ and recommendations and opinions of organizations of the European Union (E.U. $)^{6}$ and the Council of Europe (COE) ${ }^{7}$ define independence as broadly focused on structures, not a judge's inner good character. Both perspectives are essential to judicial independence. The judicial system cannot be fully independent if both categories of independence are not satisfied. A judiciary that is perfectly isolated from political interests cannot succeed without judges who are willing to resist the pressure from actors who want to influence decision-making. As well as virtuous judges cannot resist the commands from a political power if the law recognizes such command as legal. Only if both concepts are fulfilled then is secured the requirement of an independent court, that is structurally, organizationally, and functionally separate from other public authorities, a sovereign court in which impartial judges adjudicate. $^{8}$

While mindful of the "inner good" meaning of independence, this Article is about independence in the sense of insulation from state actor interference in judges' decision-making. This Article will focus on interventions from outside the judiciary, from the state agents, and their attempts to either reform or attack the judiciary.

Ultimately, what is independence in the judicial sense? ${ }^{9}$ In the narrow-and more precise sense, independence is about the insulation of a judge's decision-making from interference by the electorate and by the elected legislative and executive branches. Considered this way, judges in some legal systems are more independent than others. Furthermore, the judge performing decision-making activity must be protected from undue pressure from within the judiciary, where the pressure may come from the hierarchical and authoritarian structures of the courts, thus reducing the autonomy of individual judges. ${ }^{10}$ Independence must, therefore, be secured from outside as well as from within the judiciary.

In academia, it has become a highly debated topic. ${ }^{11}$ The phrase "judicial independence" has gained such an aura that its mere invocation is enough to end some conversations about it.

is linked to impartiality). See also Case C-503/15, Margarit Panicello v. Pilar, ECLI:EU:C:2017:126, para. 38 (Feb. 16, 2017); Case C-222/13, TDC A/S v. Erhvervsstyrelsen, ECLI:EU:C:2014:2265, para. 31 (Oct. 9, 2014); Case C-203/14, Consorci Sanitari del Maresme, ECLI:EU:C:2015:664, para. 20 (Oct. 6, 2015); Case C-506/04, Graham J. Wilson v. Ordre des avocats du barreau de Luxembourg, ECLI:EU:C:2006:587, para. 52 (Sept. 19, 2006).

${ }^{5}$ The European Court of Human Rights (Eur. Ct. H.R.) distinguishes between external and internal independence, where internal independence acquires the definition: "([I]ndependence) requires that they be free from directives or pressures from the fellow judges or those who have administrative responsibilities in the court such as the president of the court or the president of a division in the court." Parlov-Tkalčić v. Croatia, App. No. 24810/06, para. 86 (Dec. 22, 2009), http:// hudoc.echr.coe.int/fre? $\mathrm{i}=002-1194$. Thus, internal judicial independence in Eur. Ct. H.R. case law regulates the relationship between judges, such as that between a member of a judicial panel and its chairman, but it also pertains to the relationship between a judge and 'his' court executives. See, e.g., Joost Sillen, The Concept of 'Internal Judicial Independence' in the Case Law of the European Court of Human Rights, 15 Eur. CONST. L. REv. 104, 111 (2019).

${ }^{6}$ See European Network of Councils of the Judiciary, IndePendence, Accountability and Quality of The JUDICIARY (2016-2017), https://www.encj.eu/images/stories/pdf/workinggroups/independence/encj_report_ia_ga_adopted_ ga_13_6.pdf [https://perma.cc/VTH5-VWWM] (In which the European Network of Councils of the Judiciary (ENCJ), the consultative institution of the European Commission distinguishes between the objective independence of the judiciary as a whole and the objective and subjective independence of the individual).

${ }^{7}$ Consultative Council of European Judges (CCJE), the consultative organizations of the Council of Europe (CoE), differentiates between statutory, functional, and financial independence. CCJE, Magna Carta of Judges (Nov. 17, 2010), https://rm.coe.int/ 16807482c6 [https://perma.cc/MP6Q-A7DT] [hereinafter Magna Carta of Judges]. CCJE, Opinion no. 1 (Nov. 23, 2001).

${ }^{8}$ See Katarzyna Gajda-Roszczynialska \& Krystian Markiewicz, Disciplinary Proceedings as an Instrument for Breaking the Rule of Law in Poland, 12 Hague J. Rule L. 451, 453 (2020).

${ }^{9}$ See, e.g., Irving R. Kaufman, The Essence of Judicial Independence, 80 Colum. L. REv. 671 (1980); Stephen B. Burbank, What Do We Mean By "Judicial Independence"?, 64 OHIо Sт. L. J. 323 (2003); Charles G. Geyh, Judicial Independence, Judicial Accountability, and the Role of Constitutional Norms in Congressional Regulation of the Courts, 78 IND. L.J. 153 (2003).

${ }^{10}$ See Sillen, supra note 5, at 104; David Kosař, Perils of Judicial Self-GovernMENT In Transitional Societies 132-33 (2017).

${ }^{11}$ See Maria Popova, Politicized Justice in Emerging Democracies: A Study of Courts in Russia and Ukraine (2012); Ramona Coman \& Cristina Dallara, Judicial Independence in Romania, in JUdicial INDEPENDENCE IN TRANSITION 
However, as some scholars have recognized, there can be too much judicial independence, and in the absence of sufficient accountability, the consequences can be grave. Such an unaccountable judiciary may lead to "favoring institutional independence of judges (or rather senior judicial officials), to the detriment of individual judicial independence and impartiality of judges," 12 up to the point of judicial supremacy. ${ }^{13}$

Therefore, independence is not an absolute value, but like most carefully defined concepts, judicial independence must be used as a matter of degree. Rather than understanding judicial independence as inevitably a "more is better" concept, we can see that there is, indeed, a "right amount of judicial independence," as Owen Fiss taught decades ago in his work on emerging democracies in Latin America. ${ }^{14}$ Judges should be protected from undue influences. However, the more the judicial power expands and penetrates both politics and society, the more it needs to be checked and held accountable. ${ }^{15}$

For a proper understanding of judicial independence, it is equally necessary to understand judicial accountability. ${ }^{16}$ As in judicial independence, accountability, too, might be portrayed on the level of personality traits and systemic arrangement. Accountability in the former sense exists as a "responsiveness and 'a sense of responsibility,' a willingness to act in a transparent, fair, and equitable way. Accountability, used in this more active sense of virtue, refers to substantive norms for the behaviour of actors." 17 On an institutional level, judicial accountability works by providing formal and informal instruments that determine standards of answerability for the judiciary ${ }^{18}$ and the judge. ${ }^{19}$ In this sense, judicial accountability represents either the mechanisms of inter-institutionalinter-branch-accountability, which ensure that no branch prevaricates and overrules the others, ${ }^{20}$ or it encompasses the negative or positive consequence that an individual judge expects to face from one or more principals - from the executive, the legislature, the court presidents, or other actors - if his or her behavior or decisions deviate too far from a generally recognized standard. ${ }^{21}$

The existence of judicial accountability in a correct measure is no threat to judicial independence. $^{22}$ Accountability must find a sensitive balance, rather than contradiction, with

835, 848 (Anja Seibert-Fohr ed., 2012); Daniela Piana, Judicial Accountabilities in New Europe: From Rule of Law to Quality of Justice (2010); Cristina Părău, The Drive for Judicial Supremacy, in Judicial IndePENDENCE In TRANSITION 665 (Anja Seibert-Fohr ed., 2012); David Kosař, Politics of Judicial Independence and Judicial Accountability in Czechia: Bargaining in the Shadow of the Law between Court Presidents and the Ministry of Justice, 13 Eur. Const. L. Rev. 96 (2017).

${ }^{12}$ Michal Bobek \& David Kosař, Global Solutions, Local Damages: A Critical Study in Judicial Councils in Central and Eastern Europe, 15 GERMAN L.J. 1257, 1290 (2014).

${ }^{13}$ See Părău, supra note 11.

${ }^{14}$ See Owen Fiss, The Right Degree of Independence, in Transition to Democracy in Latin America: The Role of the Judiciary 55 (IrWIN P. STOTZKY ED., 1993).

${ }^{15}$ See Daniela Piana, Beyond Judicial Independence: Rule of Law and Judicial Accountabilities in Assessing Democratic Quality, 9 COMPAR. Socio. 40-64, 42 (2010).

${ }^{16}$ See Kosař, supra note 10, at 30. See also David Kosař \& Samuel Spáč, Conceptualization(s) of Judicial Independence and Judicial Accountability by the European Network of Councils for the Judiciary: Two Steps Forward, One Step Back, 9 INT'L J. CT. ADMIN. 37 (2018).

${ }^{17}$ Mark Bovens, Two Concepts of Accountability: Accountability as a Virtue and as a Mechanism, 33 W. EUR. POL. 946,949 (2010).

${ }^{18}$ Objective accountability of the judiciary, such as the mechanisms for allocation of cases and efficiency of these mechanisms, complaints procedure, external participation in committees or appellate procedure. Moreover, periodic reporting by the judiciary, relations with press and familiarizing of the public or external review. See in Frans Van Dijk \& Geoffrey Vos, $A$ Method for Assessment of the Independence and Accountability of the Judiciary, 9 INT'L J. CT. ADMIN. 1 (2018).

${ }^{19}$ Objective accountability of the individual judge, such as the existence of the code of judicial ethics, its efficiency and availability. A withdrawal and recusal of the judge in cases, in which there is a doubt on her impartiality. Or admissibility of external functions of judges while holding the office of the judge. See in Frans Van Dijk \& Geoffrey Vos, A Method for Assessment of the Independence and Accountability of the Judiciary, 9 INT'L J. CT. Admin. 1 (2018).

${ }^{20}$ See Piana, supra note 15 , at 42.

${ }^{21}$ See KosAř, supra note 10 , at 17.

${ }^{22}$ For a discussion of judicial accountability in the European context, see Special Issue Measuring Judicial Independence and Accountability, in 9 INT'L. J. CourT ADMIN. 3 (Dec. 19, 2018) https://www.iacajournal.org/29/volume/9/issue/3/. 
independence. Independence and accountability are not necessarily contesting ends but can be complementary means for securing impartiality and, in turn, the rule of law. ${ }^{23}$ This balance shall reflect how the other branches of state power can influence the judiciary, including in selecting new judges, the increase or decrease in judges' salaries, or the disciplinary proceedings of judges, while still guaranteeing the insulation of decision-making from outside intervention. After all, "[t]he independence of the judiciary, as opposed to that of individual judges, is dependent on the 'willingness' of the popular branches of government to refrain from using their ample constitutional powers to infringe on judicial authority." 24

What is the aim of this balance? The accountability and autonomy in the administration of justice are crucial to secure non-interference in judicial decision-making but still having instruments to sanction arbitrariness in decision-making. The goal is to have both an impartial and legitimate judiciary. Properly understood, judicial independence is a beautiful thing-an essential element of a just and prosperous nation. ${ }^{25}$ Abused or improperly understood, judicial independence is a tool of corruption and injustice. ${ }^{26}$ The same applies to accountability. When set correctly, it leads to trustworthy courts, while when incorrectly, it leads to the subservient and obedient judiciary.

The complex structure of judicial independence and accountability can, in principle, be explained by the structure of the normative goals we wish courts to serve. ${ }^{27}$ Therefore, independence and accountability are not themselves goals but instruments for furthering other values, such as guaranteeing a fair trial or public trust. For the legal system to be effective, it must be trusted by the subjects of law. In a society claiming equality before the law, the arbiter deciding upon the conflict of parties must be impartial. Therefore, securing impartiality is a priority when striving for a working legal system, with subjects who voluntarily follow the rules because they trust the legal system's fairness. Still, what is more crucial than the impartiality of the system is the appearance of impartiality in the eyes of the subjects of law. ${ }^{28}$ Therefore, the system must be structured to provide enough assurance to the subjects that another party's arguments would not prevail only because of their influence on the arbiter when they turn to the court. No one stands above the law; the arbiter will stay impartial and uphold the rule of law.

For new democracies, where rule-of-law institutions are relatively new and achieving a balance between judicial independence and accountability is still in process, attacks and reforms may resemble one another in the early stages. The political power represented by parliament and an administration may be tempted to maintain control over the judiciary. Such control assures that the courts will accept their policies. There is a temptation toward unaccountable administration, mainly if the ambitions of administrations are on fringes or clearly against the law or constitution. Such an effort

\footnotetext{
${ }^{23}$ See Stefan Voigt, The Economic Effects of Judicial Accountability: Cross-Country Evidence, 25 Eur. J. L. EcON. 95 , 119 (2008).

${ }^{24}$ Ferejohn, supra note 2, at 382.

${ }^{25}$ See William M. Landes \& Richard A. Posner, The Independent Judiciary in an Interest-group Perspective, 18 J.L. \& EcoN. 875,879 (1975).

${ }^{26}$ See Jordan Underhill, Bribery on the Bench: A Look at Judicial Corruption, Association OF CERTIFIED FrAUD EXAMINERS, https://www.acfe.com/fraud-examiner.aspx?id=4294994669 (last visited June 19, 2021). See also Arthur Selwyn Miller, Public Confidence in the Judiciary: Some Notes and Reflections, 35 L. CONTEMP. Probs. 69, 87-92 (1970) https://scholarship.law.duke. edu/cgi/viewcontent.cgi? article=3277\&context $=\mathrm{lcp}$. See also Mauro Cappelletti, Who Watches the Watchmen? $A$ Comparative Study of Judicial Responsibility, in Judicial IndePENDENCE: THE CONTEMPORARY DeBATE 550, 574 (Shetreet \& Deschenes eds. 1985); Stephan Grimmelikhuijsen \& Albert Klijn, The Effects of Judicial Transparency on Public Trust: Evidence from a Field Experiment, 93 PUB. ADMIN. 995, 1006-07 (2015).

${ }^{27}$ See Ferejohn, supra note 2, at 356. See also Michal Bobek, The Fortress of Judicial Independence and the Mental Transitions of the Central European Judiciaries, 14 Eur. PuB. L. 99, 101 (2008).

${ }^{28}$ For tests on impartiality, see Gautrin v. France, App. No. 38/1997/822/1025-1028, para. 58 (May 20, 1998), https://hudoc. echr.coe.int/fre\#\{\%22itemid\%22:[\%22001-58166\%22]\}.
} 
of the political branches leads to "dikastophobia" - a dangerous populist strategy to prevent judges from controlling the executive and legislative powers under judicial authority. ${ }^{29}$

What, then, is that balance of independence and accountability? Where does the political effort for public good, efficacy, and trust in the judiciary fade into avoidance of political majority to be held accountable? Moreover, what action constitutes valid criticism distinguished from an attack on the independence of the judiciary? Any status quo change that establishes more accountability instruments for judges appears to be a sign that something sneaky might be taking place. Though, some accountability is necessary for promoting public trust. Other instruments of accountability are necessary for the effective administration of justice.

The attack would then be defined by the intention to interfere with the court's impartiality and avoiding accountability for the activities of the administration or its allies. The various types of attacks use different instruments for interfering with impartiality. The vulgar attacks put pressure on a particular judge deciding a case of interest, the systemic attacks attempt to rewrite the rules of the game, and insidious attacks aim to delegitimize the game itself.

This Article explores changes in Hungary since 2010, in Poland since 2015, and the recent interferences in Czechia, Slovakia, and the U.S. in recent years. Three decades after the fall of state socialism, all four Central European countries face similar problems with the backsliding of the rule of law, but we may observe different ways that actors have attempted to take control over the judiciary. ${ }^{30}$ In the U.S. experience of democratic backsliding became more prominent during the presidency of Donald Trump.

\section{Vulgar Attacks}

\section{Czech Republic: When the Brute Manners Seem Clumsy}

In its 2020 report, Freedom House concluded that the Czech Republic is a parliamentary democracy in which political rights and civil liberties are generally respected. ${ }^{31}$ Still, as in the whole region of Central and Eastern Europe (CEE), the populist movement is on the rise. ${ }^{32}$ The Prime Minister's political party ANO causes "democratic backsliding" 33 and "democratic decay." 34 He prefers to "run the state like a firm," implying that checks and balances, as well as complex

\footnotetext{
${ }^{29}$ See Katarzyna Gajda-Roszczynialska \& Krystian Markiewicz, Disciplinary Proceedings as an Instrument for Breaking the Rule of Law in Poland, Hague J. Rule L. 1, 2 (2020).

${ }^{30}$ The majority of scholarly reflections on recent Central European developments have been framed as the deterioration of the rule of law or as an attack on liberal democracy and constitutionalism. See, e.g., Gábor Halmai, From the "Rule of Law Revolution" to the Constitutional Counter-Revolution in Hungary, in EUR. YEARBOOK OF HuM. RTs. 367 (W. Bedenek ed., 2012) (For a discussion of backsliding in the CEE); Laurent Pech \& Kim Lane Scheppele, Illiberalism Within: Rule of Law Backsliding in the EU, 19 CAmbridge Y.B. Eur. STud. 3 (2017); A. von Bogdandy et al., Guest Editorial: A Potential Constitutional Moment for the European Rule of Law - the Importance of Red Lines, 55 COMMON MKT. L. REV. 983 (2018).

${ }^{31}$ See Czech Republic: Freedom in the World 2020 Country Report, FrEEDOM House, https://freedomhouse.org/country/ czech-republic/freedom-world/2020 (last visited May 26, 2021).

${ }^{32}$ See Seán Hanley \& Milada Anna Vachudova, Understanding the Illiberal Turn: Democratic Backsliding in the Czech Republic, 34 E. EUr. POL. 276 (2018).

${ }^{33}$ See Pech \& Scheppele, supra note 30, at 9-10 (Discussing a process through which elected public authorities deliberately implement governmental blueprints which aim to systematically weaken, annihilate or capture internal checks on power with the view of dismantling the liberal democratic state and entrenching the long-term rule of the dominant party. This process enables the establishment of electoral autocracies and the solidification of one-party states in which elected officials of the ruling party claim exclusive authority to act on behalf of "the people".). See also Gero Erdmann, Decline of Democracy: Loss of Quality, Hybridisation and Breakdown of Democracy, in REGRESSION OF DEMOCRACY? 21 (Erdmanm \& Kneuer eds., 2011) ("Changes in formal or informal institutions that move the polity in the direction of a hybrid or authoritarian regime. ...").

${ }^{34}$ See Petra Guasti, Populism in Power and Democracy: Democratic Decay and Resilience in the Czech Republic (2013-2020), in Politics AND Governance 473 (8th ed. 2020) (Explaining that democratic decay is operationalized as the decline in horizontal, vertical, and diagonal accountability).
} 
procedural rules, are nothing but a nuisance. ${ }^{35}$ The Czech Republic has seen "the emergence of new parties with some characteristics of populism, but they lack the nationalistic, authoritarian, and anti-liberal streak seen elsewhere. Instead, these parties have embraced technocratic and entrepreneurial solutions." 36 The situation differs from that of Poland and Hungary. The public distrust towards government is noticeable ${ }^{37}$ but not so strong as to turn the public toward non-democratic alternatives. ${ }^{38}$

Unlike in Poland and Hungary, where institutions were attacked after Fidesz and PiS (Law and Justice Party) rose to power, the political rise of Andrej Babiš and ANO has undermined already weak informal liberal democratic institutions in areas such as financial transparency, conflict of interest, manipulation of the state administration and accountability to the media. ${ }^{39}$ First, the accumulation of the Prime Minister's economic power and ownership of media happened before he entered politics. Second, the influence of Babiš in the economy and the media served as a substitute for - or an alternative to - the political party and civil society structures built by Fidesz and PiS. Third, this power has accumulated in the hands of one individual, Babiš. Fourth, the type of populism that Babiš and ANO have used to appeal to voters is more technocratic than nationalist; it is organized around the fight against corruption by an establishment elite cabal. ${ }^{40}$ This type of leading government politics, called technocratic populism, rejects vertical and horizontal accountability.

This shift began in 2013 when Babiš was a junior partner in Prime Minister Sobotka's government, and in 2017 Prime Minister Babišs's government continued to undermine the accountability of political power. ${ }^{41}$ This led to a wave of protests in 2019, from April to June and again in November, calling for the resignation of Babiš for his role in a corruption scandal involving European Union subsidy fraud, a scandal nicknamed Stork's Nest. The protests were the largest in the Czech Republic since the Velvet Revolution. ${ }^{42}$ The uproar intensified after the abrupt resignation of the minister of justice after the police recommended the prosecution of Babiš. The subsequent appointment of Marie Benešová as the new justice minister raised concerns over possible attacks on the independence of the judiciary. Furthermore, Benešovás appointment was accompanied by rumors in August 2019 about the potential reform of the prosecutor general's office, which was the main force behind the Babiš investigation. ${ }^{43}$ In September the state attorney

\footnotetext{
${ }^{35}$ See David Kosař, Jiř́ Baroš \& Pavel Dufek, The Twin Challenges to Separation of Powers in Central Europe: Technocratic Governance and Populism, 15 Eur. Const. L. Rev. 427, 451 (2019).

${ }^{36}$ Andrew Roberts, Czech Democracy in the Eyes of Czech Political Scientists, 33 E. Eur. Pol. 562, 590 (2017).

${ }^{37} \mathrm{Na}$ Letné demonstrovalo čtvrt milionu lidi, nejvíc od roku 1989 [A quarter of a million people have been demonstrating at Letná, most since 1989], CZECH NEwSPAPER (June 23, 2019), https://www.ceskenoviny.cz/zpravy/na-letne-demonstrovaloctvrt-milionu-lidi-nejvic-od-roku-1989/1770584 (Czech).

${ }^{38}$ See Roberts, supra note 36, at 564 (Among the political deficiencies are non-rationalized parliamentarism caused by proportional representation leading to ineffective governments, or deficiencies in political culture such as lack of respect for rules resulting in corruption, lack of political participation via party politics and a generally bad reputation of the activity of "politics" seen as predatory and corrupt. This belief results in corporativism of the parties and a lack of understanding of the good, steady process of individualization and pursuit for economic wealth, that does not comply with public service, inability to communicate politically on matters that seek compromise, or disenchantment of transition, that did not deliver more social justice.).

${ }^{39}$ See Hanley \& Vachudova, supra note 32, at 290.

${ }^{40} I d$. at 289.

${ }^{41}$ Guasti, supra note 34 , at 475 .

${ }^{42}$ Karolína Vaverková, Druhá Letná předčila očekávání. Demonstrovali i šéfové opozičních stran [The Second Letná Exceeded Expectations. The Leaders of the Opposition Parties also Demonstrated], ECHO24 (Nov. 17, 2019), https://echo24.cz/a/SCwnL/ druha-letna-predcila-ocekavani-demonstrovali-i-sefove-opozicnich-stran (Czech).

${ }^{43}, Z a z n i ́ v a l y ~ p o c h y b n o s t i . ' O$ novele zákona o státním zastupitelství jednala legislativní rada sedm hodin ["There were doubts.” The Legislative Council Discussed the Amendment to the Public Prosecutor's Office Act for Seven Hours], CZECH RADIO (Sept. 12, 2019), https://www.irozhlas.cz/zpravy-domov/novela-statni-zastupitelstvi-marie-benesova-pavel-zeman 1909121856_jak.
} 
halted the prosecution of Babiš for his alleged involvement in the Stork's Nest scandal. Though the case was reopened in December, public protests voiced disappointment at handling the case. ${ }^{44}$

Several aspects of the situation are noteworthy, particularly the responsive civil society and the strong distrust held by the public toward branches of the state that hold political power. Even though the ANO movement is characterized as populist and Babiš has been continually accumulating power, no systemic attack on the judiciary has taken place. Despite the populist shift in politics, any attempts to attack the judiciary have appeared more clumsy or vulgar than democracy-threatening. The attacks were perpetrated with brute force or direct command. When the attacks are against a stable institutional framework, they appear more like an awkward attempt than a real threat. In the stable institutional framework of the rule of law, such an attack is reminiscent of a bully, who is considered rude and dishonest.

When such attempts are unsuccessful, they represent offensive, brute force used against a judiciary to further one's own interest. ${ }^{45}$ Whether putting pressure on a member of the judiciary ends as a misguided attempt or actual corruption is critical. The difference can be seen with the former Czech Supreme Court President Baxa, who revealed that in 2019 he was approached by then-president Zeman's advisor. Baxa was offered a nomination for a seat at the Constitutional Court of the Czech Republic if he assured that the Supreme Administrative Court delivered a decision for the president. ${ }^{46}$ Zeman's advisor also approached a judge of the Czech Constitutional Court with a similar offer. ${ }^{47}$

The Czech judiciary has stayed mostly independent, though its multi-layered composition has led to some problems. ${ }^{48}$ In comparison to other countries in the CEE, the Czech judiciary is in good shape. While Czech politics are moving toward a backsliding of democratic values, this backsliding does not seem to touch the courts. We will look at the pillars of that stability.

\section{Public Trust}

The Czech judiciary enjoys high public trust in comparison to other countries in the region. The perceived independence of courts and judges among the public has risen in recent years to fifty-six percent. ${ }^{49}$ The same criteria surveyed among companies is at forty-four percent. The Supreme Court enjoys the trust of seventy percent of the public, while the Supreme Administrative Court and the Constitutional Court have the trust of sixty-eight percent and sixty-seven percent of the public, respectively. ${ }^{50}$

Such high trust in judicial institutions is quite exceptional within the CEE, and the Czech Republic, unlike other Visegrad countries, never applied any of the proposed models for the Council of the Judiciary. ${ }^{51}$ Other countries from the CEE region, like Poland, Hungary, and

\footnotetext{
${ }^{44}$ See Daniel Martínek, Semi-successful Socio-political Transformation in CEE: The Case of the Czech Republic, 60 DER DONAURAum 71 (2020).

${ }^{45}$ For example, the Slovak judges who appeared in the Threema Scandal were dictated by Kočner how to decide.

${ }^{46}$ Zeman mi naznačoval: dám vám funkci, vy mně rozhodnutí, prohlásil Baxa [Zeman Hinted at Me: I Will Give You Office and You Will Give Me the Decision, Baxa said], IDNEs (Jan. 23, 2019), https://www.idnes.cz/zpravy/domaci/zeman-mynarovlivnovani-soudcu-baxa.A190123_202859_domaci_kuce(Czech).

${ }^{47}$ Hana Mazancová, O schůzkách jsem promluvil, aby mě už Mynář nekontaktoval, říká ústavní soudce Šimíček, DENík N, https://denikn.cz/49816/o-schuzkach-jsem-promluvil-aby-me-uz-mynar-nekontaktoval-rika-ustavni-soudcesimicek/ (last visited May 26, 2021) (Czech).

${ }^{48}$ See Czech Republic - République tchèque, CounCIL OF EUROPE, https://www.coe.int/en/web/greco/evaluations/ czech-republic (last visited Jun 20, 2021).

${ }^{49}$ See EU Justice Scoreboard 2020, EUROPEAn COMMISSION, Figure 44, https://ec.europa.eu/info/policies/justice-andfundamental-rights/upholding-rule-law/eu-justice-scoreboard_en (last visited May 26, 2021) (Showing that, in 2018 and 2019, it was fifty-one percent).

${ }^{50}$ See Hodnocení českého soudnictví, STEM, https://www.stem.cz/hodnoceni-ceskeho-soudnictvi/ (last visited May 26, 2021) (Czech).

${ }^{51}$ See Consultative Council of European Judges (CCJE), Opinion no. 10 (2007) (Nov. 23, 2007), https://rm.coe.int/ 168074779b. For information on the Euro-model, see Bobek \& Kosař, supra note 12.
} 
Slovakia, that decided to build an independent body representing either autonomy or legitimacy of the judiciary either face much lower confidence in the judiciary or substantial interference from political power. ${ }^{52}$

Even though the Czech judiciary enjoys the highest public trust in the region, international organizations have raised some objections to the country's justice system. One objection on the appointment of the presidents of the courts and the selection of the judges ${ }^{53}$ was partly solved with a change in rules for promotions to the Supreme and Supreme Administrative Courts. The selection of judges is laid down only on the level of governmental regulation. ${ }^{54}$ Other objections included the absence of a code of ethics for judges, the lack of detail in provisions on judges' extrajudicial activities, and the absence of the appellate level in disciplinary proceedings of judges. ${ }^{55}$ The World Bank objected to the non-existence of a court dedicated to hearing commercial cases or a small-claims court, the use of a manual process for assigning cases, the lack of overall standards for the timing of key court events and adjournment, the lack of electronic case management tools for lawyers, and the irregularity of publishing judgments. ${ }^{56}$ In other words, no serious breakdowns of the independence have happened yet in comparison to other CEE countries.

\section{Ministerial Model}

The Czech Republic did not amend the institutions in place and continued with its ministerial model of judiciary administration after accession to the E.U. The system has its roots in Austro-Hungarian tradition, and as Kühn writes:

[T] he Czech Republic has maintained the most extreme system of centralized management of the courts, performed by the Ministry of Justice . . . the old-fashioned and problematic system is defended just because of its age. In this view, the system has achieved its inherent value because it existed prior to the advent of the communist regime. ${ }^{57}$

The law on courts and judges in the Czech Republic establishes judicial power by independent courts. ${ }^{58}$ Judges have tenure, with strict limitations on the termination of their office. The selection of the candidates for judicial office depends on the presidents of regional courts, who submit the

\footnotetext{
${ }^{52}$ See EUROPEAN COMMISsion, supra note 49 (Finding confidence levels of forty-eight percent among public and sixteen percent among companies in Hungary, thirty-three percent among public and twenty-seven percent among companies in Poland, and only twenty-seven percent among public and fifteen percent among companies in Slovakia).

${ }^{53}$ See Group of States aGainst Corruption (GRECO), Fourth Evaluation Round, Czech Republic, at 36 https://www. coe.int/en/web/greco/evaluations/czech-republic (last visited Aug 25, 2021) (Showing that GRECO recommends (i) regulating in more detail the recruitment and promotion of judges and court presidents so as to provide for uniform, transparent procedures and to ensure that decisions are based on precise, objective and uniform criteria, notably merit; and (ii) ensuring that any decisions in those procedures are reasoned and can be appealed to a court.)

${ }^{54}$ See Regulation no. 382/2017 Sb. (Czech).

${ }^{55}$ See Group of States AgAinst CORRUPtion, supra note 53 (noting that none of these recommendations were implemented).

${ }^{56}$ See Let's Judge the Judges: How Slovakia Opened Its Judiciary to Unprecedented Public Control, TRANSPARENCY InTERNATIONAL SLOVENSKo (Feb. 28, 2018), https://transparency.sk/sk/lets-judge-the-judges-how-slovakia-opened-itsjudiciary-to-unprecedented-public-control/ (stating that the level of transparency of the judiciary is low in comparison with neighbouring Slovakia). See also Jakub Michálek, Aktuální stav soudnictví., 3 JURISPRUDENCE 30 (2020) (arguing that judges do not publish the information on their potential conflicts of interest—based on their assets declaration or family ties); Doing Business in the Czech Republic, PP AGENCY S.R.o 49, https://issuu.com/ppagency/docs/doing_business_2019_web (last visited Aug 23, 2021). Published are decisions of higher courts- Constitutional Court, Supreme Administrative Court, Supreme Court, regional courts, but lower courts publish only randomly. It is always a possibility to ask for the decision on basis of the law on free access to information. no. 106/1999 Coll/Sb.

${ }^{57}$ Zdeněk Kühn, Judicial Administration Reforms in Central-Eastern Europe: Lessons to be Learned, in JUDICIAL IndePendence In Transition 603, 606 (Anja Seibert-Fohr ed., 2012). See also Bobek, supra note 27.

${ }^{58} \mathrm{See}$ On Courts, Judges, Assessors and State Court Administration and amending some other Acts (the Act on Courts and Judges), Section 1 of act No. 6/2002 Sb. (Czech); Ústavní zákon č. 1/1993 Sb., Ústava České Republiky [Constitution of the
} 
proposals for new judges to the minister of justice. The justice minister forwards the candidates to the president of the country to be appointed, with confirmation needed from the prime minister or another cabinet member. ${ }^{59}$ The justice minister and court presidents are the traditional leaders in the Czech court administration. ${ }^{60}$ Some have pointed out deficiencies in this model.$^{61}$ There is a lack of separation of power, with possibilities for manipulation by the ministry of justice ${ }^{62}$ Furthermore, the lack of a formally designated representative body of the judiciary, when the highest instance of the administration of the justice system is the justice minister, leads to the option of contacting the representatives of the courts based on justice minister's preference for cooperation. ${ }^{63}$ This criticism is found in many international documents and academic writings favoring a judicial council model and structural independence. ${ }^{64}$

While on paper the ministerial model may seem dangerous for the independence of the judiciary, the situation has been different in practice. The other branch of criticism of the Czech model is aimed at the practical experience with the model, and it is based on the argument of the ineffectiveness of the Ministry of Justice due to the fluctuation of ministers, a lack of competence, unaccountability, and missing dialogue with the representatives of the judiciary. ${ }^{65}$ What unites both criticisms of the ministerial model is an argument against the "only 'correct' model of judicial self-administration" 66 and the controversial experience of the neighbors with Euro-model type of the Council for the Judiciary, particularly in Slovakia. ${ }^{67}$

The bridge between the justice minister and the presidents of the courts is necessary for a judge's appointment, transfer, or promotion and other personnel matters. ${ }^{68}$ It seems like a balanced relationship. Nevertheless, with a closer look, the presidents of the courts have a much more solid position in this relationship than the justice minister does. ${ }^{69}$ In less than twenty-eight years, the Czech Republic had a total of twenty-one terms of justice ministers, ${ }^{70}$ while court presidents usually serve their whole term. This creates a substantial information inequality in favor of the court presidents, and it institutionally supports the stability of the judiciary.

A strong position of judicial power is visible in the example of Minister of Justice Pospísil's reform of disciplinary proceedings against judges in 2008. Amendment 314/2008 on the law

Czech Republic]. Charter of Fundamental Rights of the European Union, Mar. 30, 2010, 2010 O.J. (C 83) 389. European Commission, Proclamation by the Commission, Dec. 7, 2000, 2000 O.J. (C 364) 1, art. 36.

${ }^{59}$ Constitution of the Czech Republic, art. 63, para. 3 .

${ }^{60}$ No. 6/2002 Sb., art. 119 (Czech) (Showing that MoJ is the central body of the state administration of courts). Other bodies of the administration of courts are presidents and vice-presidents of the courts, art. 119/2. See also Michal Bobek \& David Kosař, supra note 12 , at 1265 :

It is misleading to claim that judges themselves play no role in the appointment and promotion of judges or in the administration of courts and court management in this model and that the national Ministry of Justice controls all these processes unilaterally... it is also other bodies, such as the legislature, the President of a given country, judicial boards, the ombudsman or professional organizations, which often play a significant role or at least have their say as well ... and crucial role in these systems is in fact played by presidents of appellate and supreme courts.

${ }^{61}$ See Pavel Šámal \& Katarína Deáková, Teoretické a praktické aspekty spojené se správou justice, 25 ČASOPIS PRO PRÁVNí VĚDU A PRAXI 521 (2017).

${ }^{62}$ See Kühn, supra note 57.

${ }^{63}$ See Š́mal \& Deáková, supra note 61, at 532.

${ }^{64}$ See Bobek \& Kosař, supra note 12.

${ }^{65}$ See Šámal \& Deáková, supra note 61, at 532.

${ }^{66}$ See Michal Bobek, The Administration of Courts in the Czech Republic: In Search of a Constitutional Balance, 16 EuR. PUB. L. 251, 254 (2010).

${ }^{67}$ See Bobek \& Kosař, supra note 12. See also Kühn, supra note 57, at 617 ("Judicial councils which are too strong or omnipotent bring with them the tendency to insulate the judiciary from real life and avoid any accountability for the problems within the judiciary (Hungary)"); Bobek, supra note 27.

${ }^{68}$ See David Kosař, Politics of Judicial Independence and Judicial Accountability in Czechia: Bargaining in the Shadow of the Law Between Court Presidents and the Ministry of Justice, 13 Eur. Const. L. Rev. 96, 106 (2017). See also Kosař, supra note 10.

${ }^{69}$ See Adam Blisa, Tereza Papoušková \& Marína Urbániková, Judicial Self-Government in Czechia: Europe’s Black Sheep?, 19 GERMAN L.J. 1951, 1952 (2018).

${ }^{70}$ Out of twenty-one, two are cases of substituting Minister, and two names repeat themselves in that list. 
on courts and judges was supposed to be a hammer on judges, but it did not bring the expected outcomes. On the contrary, statistically, it brought fewer disciplinary proceedings against judges. ${ }^{71}$ In 2007 Pospísil introduced the proposal for the reform of disciplinary proceedings of judges, and in 2008 the bill passed the National Assembly. ${ }^{72}$ The bill created strong disagreements among judges. It heralded a significant change of disciplinary proceedings by moving the jurisdiction for disciplinary trials from higher courts and the Supreme Court to the Supreme Administrative Court. This move changed the double-level proceeding into single-level, without an option to appeal the decision and strengthen the representation of non-judges in disciplinary panels. This amendment of the law on judges ${ }^{73}$ was challenged at the CCCR, which decided that the law does not violate the constitution. ${ }^{74}$ Still, this amendment did not have its intended effect. ${ }^{75}$ It is more likely to compel the opposite. The number of disciplinary proceedings decreased, and sanctions became softer. ${ }^{76}$ "Pospisil's attempt to gain some cheap populist points in the campaign against fake judicial collegiality did not bring any outcomes."77

Another attempt by the Ministry of Justice to strengthen the influence of the justice minister was announced in 2016, this time focusing on changing the rules on selecting judges and preventing candidates without trial experience from entering regional courts. ${ }^{78}$ Due to strong opposition from the judiciary, the reform was postponed indefinitely. Under the second government of Babiš, the fear of interference into the judiciary resurfaced when Marie Benešová was appointed as Minister of Justice in 2019. She had been perceived as a strong supporter of President Zeman's interests and clashed with the prosecutor general, who oversees the ongoing investigation into Babiš and his family. In 2019 Benešová introduced a new judiciary reform that would shorten the term of the current prosecutor general, thus enabling the PM to nominate a "friendlier" figure. ${ }^{79}$ Experts and the judiciary saw the move as political interference and an attempt to curtail the judiciary's independence. "The reform was dead on arrival-rejected by the judiciary, the public, and the parliament." 80

Every attempt in recent years at any type of interference with the judiciary has fallen in the face of the judiciary's strong resilience. All these outcomes show who the real key player is in the Czech administration of the courts. As Kosař points out:

[T] he most important phenomenon since the Velvet Revolution, which explains this puzzle, is the rise in power of court presidents who play an intriguing twin role in ensuring judicial independence ... Czech court presidents have managed, step-by-step, to erode the Minister's sphere of influence and have themselves become the most powerful players in the Czech

\footnotetext{
${ }^{71}$ David Kosař \& Tereza Papoušková, Přinesla, Pospišilova "reforma kárného řízení skutečně zpřísnění kárného postihu českỳch soudcu?, 25 ČASOPIS PRO PRÁVNí VĚDU A PRAXI 219 (2017) (Czech).

${ }^{72}$ Zákon, kterým se mění zákon č. 6/2002 Sb [Act amending Act No. 6/2002], Zákon č. 314/2008 (Czech).

${ }^{73}$ Zákon č. 6/2002 Sb. (Czech).

${ }^{74} \mathrm{Nález}$ Ústavního soudu ze dne 29.05.1997 (ÚS) [Decision of the Constitutional Court of May 29, 1997], sp.zn. III. ÚS 31/ 97 publ. in: Sbírka nálezů a usnesení ÚS, sv. 8, č. 66 (Czech).

${ }^{75}$ See František Korbel, Ministerská “ novela zákona o soudech a soudcíc, in KOSǍ̌ \& PAPOUŠKOVÁ, supra note 71 , at 225 (Demonstrating that the aim of the amendment was to achieve a certain tightening and restoration of the credibility of the disciplinary system in the eyes of the public, for this was severely tarnished by several exemplary examples of state solidarity between judges and inconsistency or the manifestly disproportionate mildness of certain disciplinary judgments, in particular the Supreme Court).

${ }^{76}$ See Blisa, Papoušková \& Urbániková, supra note 69, at 1967.

${ }^{77}$ Kosař \& Papoušková, supra note 71, at 221 (citing Jaromir Jirsa, Soudcovská nezávislost a kárné ř́zení., 16 SOUDCE 8 (2011)).

${ }^{78}$ Guasti, supra note 43 , at 478 .

${ }^{79}$ Zaznívaly pochybnosti.' O novele zákona o státním zastupitelství jednala legislativní rada sedm hodin ["There were doubts." The legislative council discussed the amendment to the Public Prosecutor's Office Act for seven hours], CzECH RADIO (Sept. 12, 2019), https://www.irozhlas.cz/zpravy-domov/novela-statni-zastupitelstvi-marie-benesova-pavel-zeman_ 1909121856_jak.

${ }^{80}$ Guasti, supra note 34 , at 478 .
} 
judiciary, able to wield the most effective 'stick' (disciplinary motion) and 'carrot' (promotion) against individual judges. ${ }^{81}$

Court presidents of higher courts seem to fill that gap of the missing single representative body of the judiciary, and quite successfully, they together are the main actors in securing judicial independence.

As Blisa and Kosař conclude:

The court president as a judicial leader is not as strong as Russian court presidents because he is not a boss who may to a great extent affect the well-being of rank-and-file judges. However, she still has not only broad ambassadorial and media power, but also has a major say in case assignment and panel composition (administrative power). In addition, she usually wields significant jurisprudential power through setting the rules of the debate opinion assignment and shaping the law, has major say over judicial careers, either in selecting and disciplining or in promoting. ${ }^{82}$

This bridge between the justice minister and the presidents of the courts is dynamically balanced, adjusting itself to new situations. For instance, in 2008 the Czech Parliament introduced a nonrenewable term for court presidents that reduces their influence within the Czech judiciary. ${ }^{83}$ Possible favoritism leading both ways between the justice minister and presidents of the courts was confirmed by the decision of the CCCR, and the presidents may not be appointed to the positions repeatedly. This might prevent a situation in which the president would try to comply with justice minister to secure their position in the next term. ${ }^{84}$

Three events from 1999 to 2006 show the dramatic change in the position of the presidents of the courts. In 1999 Justice Minister Otakar Motejl dismissed five of eight regional court presidents. Apart from the critique of the remaining president, this event spurred no significant outrage. ${ }^{85}$ The 2005 dismissal of a president of a district court was declared unjustified. ${ }^{86}$ While the dismissed court president challenged that the minister's decision failed to meet legal requirements, the minister claimed that the court president is a public servant and that her rights were not infringed. The Municipal Court annulled the decision of the justice minister. ${ }^{87}$

Finally, in 2006, then-President Vaclav Klaus dismissed the Supreme Court President Iva Brožová, who challenged the decision. The CCCR claimed it was unconstitutional when the representative of the executive branch dismissed representatives of judicial power. ${ }^{88}$ Since 2006 neither the president nor the justice minister has been allowed to dismiss a court president.

\footnotetext{
${ }^{81}$ Kosař, supra note 68 , at 97.

${ }^{82}$ Adam Blisa \& David Kosař, Court Presidents: The Missing Piece in the Puzzle of Judicial Governance, 19 GeRMAN L.J. 2031, 2063 (2018).

${ }^{83} \mathrm{Id}$. at 2067.

${ }^{84}$ III US 31/97 Snu.(Czech) (Stating that their term is limited by seven years, President of the Supreme Court is appointed for 10 years. The presidents of higher courts are selected by the committee where judges represent the majority, and the President is appointing them to the office on proposal of MoJ. The presidents of district courts are appointed by the MoJ.). See also Articles 102-05 of Law no. 6/2002 Sb., on Courts and Judges (Czech).

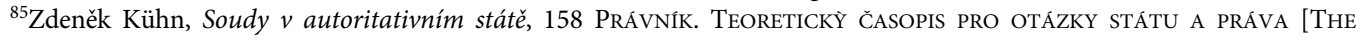
Lawyer-Scientific Review for Problems of State and Law] 981, 988 (2019).

${ }^{86} I d$. (citing Městský soud v Praze ze dne 24.07.2005 (MS) [Decision of the Circuit Court in the City of Prague Administrative Division], čj. Ca 37/2005-42 (Czech.)).

${ }^{87}$ See Michal Bobek, The Administration of Courts in the Czech Republic: In Search of a Constitutional Balance, 16 EUR. PUB. L. 259 (2010).

${ }^{88}$ See Nález Ústavního soudu ze dne 11.7.2010 (ÚS) [Decision of the Constitutional Court of July 11, 2006], sp.zn. III ÚS 7 $18 / 06$ (Czech) ("It is an indispensable requirement for safeguarding the independence of the judiciary that the conditions influencing the selection, recruitment, appointment, career advancement or removal from office of judges allow for independence from the executive and legislative powers ....").
} 
The court presidents are no longer accountable to the justice minister, and the threat to independence hidden in the justice minister's position of "transmission belts" has been reduced. ${ }^{89}$

These battles with executive and judicial representatives led to a strengthening of the position of the court presidents. The minister of justice came to view them as partners rather than servants. Pavel Rychetský, the former vice-prime minister (1998-2003) and minister of justice (2002-2003) put it frankly when asked, "What is the personal politics of a minister of justice?" and answered, "The one that fulfills the wishes of the regional court presidents."

This development led to a fragile balance between the power of court presidents and the justice minister. The new balance of power has had three noticeable effects. First, court presidents began to unite across hierarchical layers and across branches of the Czech judiciary to create greater leverage vis-à-vis the minister of justice. Second, both the minister of justice and court presidents try to exploit their powers fully while waiting for the other side to make mistakes. Third, a sideeffect of this continuing struggle is the increasing public scrutiny of the actions taken by the Ministry of Justice and court presidents. ${ }^{91}$

Such a balance provides a relatively dynamic and responsive system that discourages sudden changes. The power is dispersed across political and judicial actors. As mentioned, while at first sight, the ministerial model appears as a system left to the mercy of the justice minister, it seems to be the opposite in practice. The Czech example shows that a judiciary can enjoy a reasonable level of public confidence even without adopting a solid model of judicial self-government or establishing a judicial council. ${ }^{92}$

Perhaps this tension between the court presidents and the justice minister does not allow any actors to attack the other branch. Such a strong position of the presidents of courts, upheld by the public trust, enables the judicial representatives to resist even potential attacks that are not systemic in nature-changing the legal framework of the structure of the judiciary or dismantling the perception of the legitimacy held by the judges - or focused on gaining immediate power. If attacks are resisted and revealed to the public, the offender appears clumsy. When an attempt to interfere with judicial impartiality occurs and is exposed as such, the defending institutions become more vital as they display their resilience.

\section{Slovakia: When the Brute Manners Lead to Loss of Legitimacy}

Unlike in the Czech situation, where informal interferences ended clumsily, in Slovakia the situation became one of widespread judicial corruption. In August 2019 Slovak newspapers first published news about the communications of the infamously corrupt businessman Marian Kočner using the Threema application. After seizing Kočner's phone, the Slovak police and the Europol decoded encrypted messages that Kočner had sent through Threema in 2017 and 2018. Transcripts of the conversations that appeared in the press suggested far-reaching manipulation of court cases in Kočner's favor, and communications published later detailed instances of inappropriate communication between the judges and Kočner. In sum, nineteen judges were accused of corruption, and several advocates are facing charges of corruption and obstruction of justice. ${ }^{93}$

\footnotetext{
${ }^{89}$ See David Kosař \& Samuel Spáč, Post-communist Chief Justices in Slovakia: From Transmission Belts to Semi-autonomous Actors?, 13 HaGUe J. Rule L. 107 (2021) (Detailing this trope of transmission belts, known from Czechoslovak judiciary under the rule of the Communist Party, "presidents, who could be recalled by the Communist Party anytime at a whim, were the conduit of the Communist Party influence over individual judges. The main role of the court presidents was thus to 'transmit' orders from the Communist Party to individual judges in sensitive cases.").

${ }^{90} I d$. at 109.

${ }^{91}$ Kosař, supra note 68 , at 113 .

${ }^{92}$ Blisa, Papoušková \& Urbánikovásupra, supra note 69, at 1971.

${ }^{93}$ See, e.g., Kočner's Judges Charged and Detained, The SlovaK Spectator (Mar. 11, 2020), https://spectator.sme.sk/cl 22355425/kocners-judges-charged-and-detained.html?ref=av-left,; Kočner's Judges: Who Has Stepped Down Because of
} 
The judges involved in the allegations were delivering judgments on demand. Some of them did so for financial gain, while others acted under the threat of pressure. After the revelations of 2019 and 2020, the Slovak public learned that organized crime bosses, like Kočner, have had a high level of control over a cadre of Slovak judges through the medium of the state secretary and some court presidents. ${ }^{94}$ Although the attacks on judges have come from a state actor-the state secretarythe initiative is from the organized crime world. Further, the state secretary is herself a judge by training and career, even having briefly returned to a judicial position after leaving the Ministry of Justice under heavy scrutiny. ${ }^{95}$

The Slovak situation is elaborated in detail in Peter Čuroš piece Panopticon of the Slovak Judiciary later in this Special Issue.

\section{Systemic Attacks}

\section{Poland}

The situation in Poland is now well documented. ${ }^{96}$ This chapter will only touch on the most salient events in summary form rather than recount the entire series of events since the PiS government won power in 2015. Before winning a majority of parliamentary seats in the 2015 election, PiS announced a significant piece of its philosophy_ "legal impossibilismus." ${ }^{\text {" Th }}$ This concept essentially means that major reform cannot be undertaken in post-communist countries because of the entrenched interests and power of various elites, including judges. ${ }^{98}$ Adherence to this philosophy set the stage for PiS's efforts to disempower the courts, ostensibly to make its reforms possible.

The PiS critique of the judiciary was harsh, and, in part, was designed to diminish public trust in the judiciary to such a degree that its disempowerment laws would not be too vehemently opposed. The party retained a Washington, D.C. consulting firm, White House Writers Group, for an English-language campaign with five objectives, including the following:

Threema So Far? (Overview), The SlovaK Spectator (Nov. 5, 2019), https://spectator.sme.sk/c/22252665/kocner-judgesthreema-resignations-overview-judiciary.html?ref=av-right; Judge Steps Down for Exchanging Messages with Kočner, THE Slovak Spectator (Oct. 21, 2019), https://spectator.sme.sk/c/22241871/judge-stands-down-for-exchanging-messageswith-kocner.html?ref=av-right; Jankovská had Judges on Call for Kočner, THE SLOVAK SPECTATOR (Oct. 3, 2019), https:// spectator.sme.sk/c/22227698/jankovska-had-judges-on-call-for-kocner.html?ref=av-right; Two Witnesses Talk About the Corruption of a Judge and State Secretary, THE SLOVAK SPECTATOR (Mar. 27, 2018), https://spectator.sme.sk/c/20790365/ two-witnesses-talk-about-the-corruption-of-judge-and-state-secretary.html?ref=tab; Police seized mobile phones of judges and ex-state secretary due to corruption suspicions, THE SLOVAK SPECTATOR (Sept. 9, 2019), https://spectator.sme.sk/c/ 22208042/police-seized-mobile-phones-of-judges-and-ex-state-secretary-due-to-corruption-suspicions.html? ref=tab; Adam Valček, Why did the Police Move Against Judges? One of Them Collaborated, ThE SlovaK SPECTATOR (Mar. 11, 2020), https://spectator.sme.sk/c/22355558/why-did-the-police-moved-against-judges-one-of-them-collaborated.html?ref= tab; Charges Against Judges Show Nobody is Inviolable, The SLOVAK SPECTATOR (Mar. 11, 2020), https://spectator.sme.sk/ c/22356338/charges-against-judges-show-nobody-is-inviolable.html?ref=tab.

${ }^{94}$ See Erik Láštic, What Now? The Failure of the Independent Judiciary in Slovakia, 4 Hum. RTs. REv. 34, https://www. humanrightscentre.org/sites/default/files/attachement/bulletin/V4humanrightsreview_Q1_2020_0.pdf (last visited August 23, 2021).

${ }^{95}$ See Jankovská Had Judges on Call for Kočner, The SlOvaK Spectator (Oct. 3, 2019), https://spectator.sme.sk/c/ 22227698/jankovska-had-judges-on-call-for-kocner.html?ref=av-right.

${ }^{96}$ See, e.g., Fryderyk Zoll \& Leah Wortham, Judicial Independence and Accountability: Withstanding Political Stress in Poland, 42 Fordham InT'L L.J. 875 (2018); Laurent Pech, Patryk Wachowiec \& Dariusz Mazur, Poland's Rule of Law Breakdown: A FiveYear Assessment of EU's (In)Action, 13 Hague J. Rule L. 1 (2021); Wojciech Sadurski, How Democracy Dies (in Poland): A Case Study of Anti-Constitutional Populist Backsliding, 1 ReVISTA Forumul JudeCATORILOR 104 (2018); Anna Śledzińska-Simon, The Rise and Fall of Judicial Self-Government in Poland: On Judicial Reform Reversing Democratic Transition, 19 GERMAN L.J. 1839 (2018); Dariusz Mazur \& Waldemar Żurek, So Called “Good Change” In THe Polish System of the Administration of Justice (2018). See also Wojciech Sadurski, Poland's Constitutional Breakdown (2019); Gajda-Roszczynialska \& Markiewicz, supra note 29, at 33; Miroslaw Wyrzykowski, Experiencing the Unimaginable: the Collapse of the Rule of Law in Poland, 11 Hague J. Rule L. 417 (2019).

${ }^{97}$ Christian Davies, Hostile Takeover: How Law and Justice Captured Poland's Courts, Freedom House (2018), https:// freedomhouse.org/report/analytical-brief/2018/hostile-takeover-how-law-and-justice-captured-polands-courts.

${ }^{98} I d$. 
Explain that the judiciary reform in Poland is crucial for the elimination of corruption, impunity and delays, which make access to justice difficult for thousands of Polish citizens every year. It is also designed to restore the checks and balances, eliminated by the Soviet-style judiciary, which the newly independent Poland inherited over a quarter of a century ago. ${ }^{99}$

Justice Minister Zbigniew Ziobro said:

The judiciary had 25 years to purify itself and conduct reforms. And they have done nothing, so they lost their opportunity. Today the democratically elected politicians need to change it. Repair of the judicial system is the most important issue for which the voters elected us. I will not retreat in the battle for justice and fairness in Poland, and I will fulfill the program whose objective is that the justice system is more protective of honest people. ${ }^{100}$

The government saw that some elements of the judiciary could be easily and predictably challenged and criticized. The government used these elements to justify a wide array of legislative control over the existing judiciary, anticipating that public outcry would be muted by the level of public mistrust of the judiciary generally and of judges, particularly. The government's public influence campaign magnified the mistrust of the latter.

Unlike in Hungary, where the majority in the single-chambered National Assembly enjoyed a constitutional majority, in Poland's two-chambered Parliament, the United Right acquired the only plain majority in elections 2015 and 2019. ${ }^{101}$ Therefore, the parliamentary majority in Poland lacked the numbers necessary to change the constitutional framework and had to follow up with reform via legislation, decisions of lower chamber of parliament, presidential appointments, and appointments of the government and minister of justice. ${ }^{102}$

With a template for what would be attacked and reformed, the Polish majority in Parliament led the Constitutional Tribunal reform, with influence in the courts' administration from the Supreme Court (S.C.) to ordinary courts.

\section{Constitutional Tribunal}

The Constitutional Tribunal was targeted first to ensure that subsequent changes could be enacted with less scrutiny. ${ }^{103}$ The Polish case started with a quite momentous court-packing strategy. As the ruling majority did not have a constitutional majority, it could not increase the number of judges. ${ }^{104}$ The timing for changing the judges of the tribunal was not ideal, but with help from President Duda, it was used to the party's advantage.

Earlier, on June 25, 2015, the Civic Platform (C.P.) government changed the law under which the tribunal judges were elected. Although the existing rule had been that the Parliament could only fill a seat on the final day of a judge's term, the new rule stated that the Parliament could elect judges months ahead of an actual opening on the court. ${ }^{105}$ Before the Parliamentary election of

\footnotetext{
${ }^{99}$ The Polish National Foundation to Launch its "Fair Courts" Campaign Abroad, TVN24 (Oct. 31, 2017), https://www.tvn24. $\mathrm{pl} /$ tvn24-news-in-english,157,m/the-polish-national-foundation-to-launchits-fair-courts-campaign-abroad,786067.html.

${ }^{100}$ Zbigniew Ziobro: Nie cofnę się $w$ walce o sprawiedliwość [Zbigniew Ziobro: I will not turn back in the fight for justice], WNP.Pl PARLAMENTARnY (Apr. 8, 2017), https://perma.cc/E4T9-PNYR.

${ }^{101}$ Prawo i Sprawiedliwosc-PiS received in 2015, 37.58 percent and in 2019, 43.59 percent in Sejm and 39.99 percent, resp. 44.56 percent in Senate.

${ }^{102}$ Jan Wintr, Politický tlak na polský justiční systém v letech 2015-2019, in NEZÁvisLOST SOUDNí MOCI 113 (Vojtech Simicek, ed. 2020) (Pol.).

${ }^{103}$ Tomasz Koncewicz, Farewell to the Separation of Powers: On the Judicial Purge and the Capture in the Heart of Europe, Verfassungsblog: On MATTERs CONSTitutional (July 19, 2017), https://verfassungsblog.de/farewell-to-the-separation-ofpowers-on-the-judicial-purge-and-the-capture-in-the-heart-of-europe/.

${ }^{104}$ David Kosar \& Katarina Sipulova, How to Fight Court-Packing?, 6 CONST. STUD. 133, 141-42 (2020).

${ }^{105}$ Kriszta Kovács \& Kim Lane Scheppele, The Fragility of an Independent Judiciary: Lessons from Hungary and PolandAnd the European Union, 51 Communist AND PosT-Communist STUd. 189, 194 (2018).
} 
2015, the governing coalition led by C.P. possessed the majority to elect the candidates to replace five judges of the tribunal, with term expirations on November 6th-three seats-and December 2nd and 7th - two seats. The term of the seventh Parliament expired on November 11th. The Parliament elected five candidates to tribunal seats on October 8th, but the president did not appoint them. One of the first steps of the newly elected eighth Parliament was to pass a law on the tribunal to reverse the previous government's nominations of those five candidates. ${ }^{106}$

Subsequently, the Sejm, the lower chamber of the Parliament, revoked the former election of the candidates and nominated its own candidates, who were immediately appointed to the position of tribunal judges by the president. ${ }^{107}$

A tribunal ruling from December 3, $2015^{108}$ claimed that the amendment of the law of the tribunal from November 19, 2015 was unconstitutional, and the tribunal ordered the president to appoint three judges that the seventh-term Parliament had elected on October 8 to replace the judges whose term ended in November. The seats of the judges leaving the tribunal in December were to be filled by the newly elected eighth Sejm. Neither the president nor the Sejm followed this decision, or one that came a week later. ${ }^{109}$ A struggle over three seats on the court was waged between PiS and the president of the Constitutional Tribunal. ${ }^{110}$ Eventually, other changes to the law regulating tribunal procedures allowed a PiS devotee to assume the position of acting court president, paving the way for the three PiS-nominated judges to take seats.

When the parliamentary majority refused accountability, the fate of the tribunal was sealed. The international reaction to the court-packing scheme has attempted to stop Poland's attack on the rule of law. ${ }^{111}$ The decision of ECtHR in XERO Flor $v$. Poland ${ }^{112}$ responds to the takeover of the tribunal. Meanwhile, the Commission and the CJEU have dealt with another wave of attacks on the Polish judiciary. The initial step of the Polish parliamentary majority in 2015 may have

\footnotetext{
${ }^{106}$ See the Act of Nov. 19, 2015, Amending the Act on the Constitutional Court, (Modifying the provision in section 137 on appointment: As the candidate had to take the oath before the President of the Republic "within thirty days of the date of [his or her] election," and that "[t]he taking of the oath shall commence the term of office of a judge of the Constitutional Court.") (Poland). See also Xero Flor v. Poland, App. no. 4907/18, para. 18 (May 7, 2021), http://hudoc.echr.coe.int/eng?i=001-210065 (Detailing how, on November 25, 2015, during its second session, the eighth-term Sejm adopted five respective resolutions on "the lack of legal effect" (w sprawie stwierdzenia braku mocy prawnej) of the resolutions on the election of five judges of the Constitutional Court adopted by the previous Sejm on October 8, 2015. It also requested that the President of the Republic refrain from receiving the oath from those judges.). See also Wojciech Sadurski, Polish Constitutional Tribunal Under PiS: From an Activist Court, to a Paralysed Tribunal, to a Governmental Enabler, 11 HAGUE J. RuLE L. 63 (2019).

${ }^{107}$ See Venice Commission, Draft Opinion on Amendments to the Act of 25 June 2015 on the Constitutional Tribunal of Poland, CDL (2016) 003 of 26 February 2016, https://www.venice.coe.int/webforms/documents/?pdf=CDL(2016)003-e (last visited May 25, 2021) (documenting how the President of the Republic received the oath from four of the judges on the night of December 2-3, and from the fifth judge on December 9, 2015).

${ }^{108}$ See, e.g., Wyrok [Judgment] of CT [Constitutional Tribunal] Dec. 3, 2015, K 34/15 (Dz. U. 2015.2129) (Pol.); Wyrok [Judgment] of CT [Constitutional Tribunal] Dec. 9, 2015, K 35/15 (Dz. U. 2015.2147) (Pol.).

${ }^{109}$ Moreover, they were denied for publishing by the government, what creates the final sage to fulfil the requirement for a ruling to become valid and binding.

${ }^{110}$ See, e.g., The Act of 22 December 2015 Amending the Act on the Constitutional Court (Pol.); Judgment of the Constitutional Court, K 8/15 (Jan. 7, 2016) (Pol.); Judgment of the Constitutional Court, K 47/15 (Mar. 9, 2016) (Pol.); Judgment of the Constitutional Court, K 39/16 (Aug. 11, 2016); The Act on the Constitutional Court of 22 July 2016; Judgment of the Constitutional Court, K 1/17 (Oct. 24, 2017).

${ }^{111}$ See Venice Commission, Poland, Opinion on the Act on the Constitutional Tribunal, Opinion 860/2016 (Oct. 14, 2016) https://www.venice.coe.int/webforms/documents/default.aspx?pdffile=CDL-AD(2016)026-e. For unsuccessful Commission Recommendations, see European Commission, Commission Recommendation (EU) 2016/1374 of 27 July 2016 Regarding the Rule of Law in Poland; European Commission, Commission Recommendation (EU) 2017/146 of 21 December 2016 Regarding the Rule of Law in Poland Complementary to Recommendation (EU) 2016/1374, 2016 O.J. (L 217); European Commission, Commission Recommendation (EU) 2017/1520 of 26 July 2017 Regarding the Rule of Law in Poland Complementary to Recommendations (EU) 2016/1374 and (EU) 2017/146, 2016 O.J. (L 228); and European Commission, Commission Recommendation (EU) 2018/103 of 20 December 2017 Regarding the Rule of Law in Poland Complementary to Recommendations (EU) 2016/1374, (EU) 2017/146 and (EU) 2017/1520, 2016 O.J. (L 17).

${ }^{112}$ Xero Flor, App. No. 4907/18.
} 
hindered the legitimacy and legality of the Polish tribunal, as the ECtHR does not recognize as lawful any of the three judges elected by the eighth-term Sejm that replaced judges nominated by the seventh-term Sejm in the nomination for the tribunal. ${ }^{113}$

\section{Changes on the Council for the Judiciary}

The amendment of the normative and personnel framework of the Constitutional Tribunal served as the basis for further changes in the justice system. After securing a favorable outcome for constitutional review, the parliamentary majority moved to its next step. With the proclaimed ambition of reforming the judiciary to enhance its democratic accountability, ${ }^{114}$ the PiS set an agenda that the international audience considered more as an attack than a reform: The changes "enabled the legislative and executive powers to interfere severely and extensively in the administration of justice and thereby pose a grave threat to the judicial independence as a key element of the rule of law." 115

The next step was "the politicization of the Council for the Judiciary (Krajowa Rada Sądownictwa, KRS) and an attempt to take over the personnel and organization of the Supreme Court." ${ }^{116}$ As the KRS is supposed to safeguard the independence of courts and judges, ${ }^{117}$ the takeover of this body is essential to seeking control over the judiciary. The KRS has a strong position in the recruitment and promotion of judges. ${ }^{118}$ Such an acquisition brings benefits long after the takeover, as it shapes lines of decision-making that can last for years.

The Polish Council for the Judiciary consists of twenty-five members. ${ }^{119}$ Before $2017,{ }^{120}$ fifteen of the twenty-five members were elected by their peers from a pool of judges. Four others were representatives of the Sejm, and two were representatives of the Senate. The President appointed one member, and the President of the Supreme Administrative Court, the President of the Supreme Court and the Minister of Justice were members.

${ }^{113} I d$. at para. 282 ("In failing to respect their duty to comply with the relevant judgments of the Constitutional Court, the actions of the legislative and executive authorities had been incompatible with the rule of law . . ."); Id. at para. 285:

[T] he authorities' failure to abide by the relevant Constitutional Court judgments was also linked with their challenging the role of the Constitutional Court as the ultimate arbiter in cases involving the interpretation of the Constitution and the constitutionality of the law. That aspect of the case had also to be regarded as undermining the purpose of the "established by law" requirement.

Id. at para. 287:

"The actions of the legislature and the executive had therefore amounted to unlawful external influence on the Constitutional Court. The breaches in the procedure for electing the three judges, including M.M., to the Constitutional Court had been of such gravity as to impair the legitimacy of the election process and undermine the very essence of the right to a "tribunal established by law."

${ }^{114}$ See Venice Commission, Poland, Opinion on the Draft Act Amending the Act on the National Council of the Judiciary, on the Draft Act Amending the Act on the Supreme Court, Proposed by the President of Poland, and on the Act on the Organisation of Ordinary Courts, CDL-AD(2017)031 of Dec. 1, 2017, para. 33, https://www.venice.coe.int/webforms/documents/default. aspx?pdffile=CDL-AD(2017)031-e (citing Memorandum on the Draft Act on the NCJ, p. 1) ("[T]he explanatory Memorandum prepared in support of this Draft Act explained the need for the reform of the Supreme Court as follows: the Polish courts have never been truly "decommunized"; collaborators of the previous regime infiltrated the judiciary and resisted all changes. As a result, the society lost trust in the courts. To re-establish this trust it was necessary to increase the democratic control over the judges and strengthen their accountability. Whether the above assessment is correct is a subject of the political debate going on in Poland at the moment.).

${ }^{115}$ See Id. at para. 129. See also CCJE-BU Statement as Regards the Situation on The Independence of the Judiciary in Poland from June 18, 2018. The CCJE responded: "Acts on the NCJ, Supreme Court and organisation of the judicial system entails a major step back as regards judicial independence, separation of powers and the rule of law in Poland."

${ }^{116}$ Wintr, supra note 102 , at 115 .

${ }^{117}$ See Konstytucja Rzeczypospolitej Polskiej [Constitution of Poland] art. 186, para. 1 [hereinafter Polish CONSTITUTION].

${ }^{118}$ See, e.g., Act of 8 December 2017 amending the Act on the National Council of the Judiciary; POLISH ConstituTION art. 179.

${ }^{119}$ See Polish Constitution, art. 187.

${ }^{120}$ See Act of 8 December 2017 amending the Act on the National Council of the Judiciary, Official Journal 2018, Item 5. 
Since the reform of $2017,{ }^{121}$ the fifteen members that had been elected by peer judges were now elected by the Sejm. This created a strong imbalance. Previously, seventeen out of twenty-five members of the KRS were chosen from within the judiciary, but after 2017, twenty-three out of twenty-five members were selected by the political branches of power. ${ }^{122}$ Due to such a change in representation, the European Network of Councils for the Judiciary (ENCJ) suspended the KRS in September 2018 and blocked its voting rights. ${ }^{123}$

\section{Supreme Court}

The Supreme Court (S.C.) is usually next to face reform or attack. In Poland, the S.C. acts as a court of "extraordinary instance," deciding in appeal proceedings and providing uniform law interpretations. ${ }^{124}$ Moreover, its formal but also practical position of authority within the judiciary is significant, and it enjoys the respect of both judges and citizens. When the political power seeks greater control over the third branch, it is logically not in its interest to be worried about resistant voices from high positions. The quick court-packing strategy, although to some extent a painful change, reduces the chances of constant critique.

A 2017 law on the Supreme Court lowered the retirement age limit from seventy to sixty-five. ${ }^{125}$ This step had significant consequences, for it signaled the end of service for almost forty percent of the judges on the Supreme Court. ${ }^{126}$ It also received a clear response from the CJEU, ${ }^{127}$ which concluded that the policy constituted discrimination.

In line with the Hungarian strategy, the number of seats of the S.C. was increased by PiS in 2017. ${ }^{128}$ Unlike with the smooth dismissal of the president of the S.C. in Hungary thanks to a

\footnotetext{
${ }^{121}$ See id.

${ }^{122}$ See Art. 9a. 1. of the Act of 12 May 2011 on the National Council of the Judiciary (Showing that the Sejm selects fifteen members of the Council from among the judges of the Supreme Court, common courts, administrative courts and military courts for a common four-year term of office).

${ }^{123}$ See ENCJ suspends Polish National Judicial Council, European NeTwOrks of CounCILS FOR THE JudiCIARY, https:// www.encj.eu/node/495 (last visited May 25, 2021). See also Gajda-Roszczynialska \& Markiewicz, supra note 8 , at 10 (Highlighting that, on 17 May 2020, the Board proposed to the General Assembly of the ENCJ, that the Polish Council for the Judiciary (KRS) be expelled as a member of the network).

${ }^{124}$ See Art. 1 of the Act of 8 December 2017 amending the Act on the National Council of the Judiciary, Official Journal 2018, Item 5.

${ }^{125}$ See Art. 37 of the Act of 8 December 2017 amending the Act on the National Council of the Judiciary, Official Journal 2018, Item 5:

A judge of the Supreme Court shall retire on the day of his 65th birthday, unless, not later than 6 months before that day and not earlier than 12 months before that day, he submits a declaration that he is willing to continue to carry out his duties and presents a certificate confirming that his health is no impediment to carrying out the duties of a judge, issued in accordance with the rules specified for candidates applying for the office of judge, and the President of the Republic of Poland grants authorisation for him to continue to carry out his duties at the Supreme Court.

${ }^{126} \mathrm{See}$ id. (Showing also that the retirement age was set to 65 years for male and 60 years for female judges, who submit a declaration for retirement). See also Venice Commission, Poland, Opinion on the Draft Act Amending the Act on the National Council of the Judiciary, on the Draft Act Amending the Act on the Supreme Court, Proposed by the President of Poland, and on the Act on the Organisation of Ordinary Courts, CDL-AD(2017)031 of Dec. 11, 2017, para. 46, https://www.venice.coe.int/ webforms/documents/default.aspx?pdffile=CDL-AD(2017)031-e; Marcin Matczak, Poland: From Paradigm to Pariah? Facts and Interpretations of Polish Constitutional Crisis (2018), at 8. https://papers.ssrn.com/abstract=3138541.

${ }^{127}$ See Case C-619/18, Comm'n v. Republic of Poland, ECLI:EU:C:2019:531 (Jun. 24, 2019) https://eur-lex.europa.eu/legalcontent/EN/TXT/PDF/?uri=CELEX:62018CJ0619\&from=EN:

[B]y lowering the retirement age of the judges appointed to the Supreme Court and by applying that measure to the judges in post appointed to that court before 3 April 2018 and, second, by granting the President of the Republic the discretion to extend the period of judicial activity of judges of that court beyond the newly fixed retirement age, the Republic of Poland has failed to fulfil its obligations under the combined provisions of the second subparagraph of Article 19(1) TEU and Article 47 of the Charter of Fundamental Rights of the European Union ('the Charter').

${ }^{128}$ See Wojciech Sadurski, Poland's Constitutional Breakdown 146 (2019) ("From 82 to 120. this, according to conservative assessments, creates vacancies of about 60 percent of all judges on the SC, to be filled of course by a "new" KRS.").
} 
constitutional majority, the Polish First President of the SC Małgorzata Gersdorf ${ }^{129}$ fought the parliamentary majority's attempts to replace her.

Moreover, the law on the S.C. created two new chambers that the KRS filled right after the alteration of its member composition. These chambers were the Disciplinary Chamber (D.C.) and the Extraordinary Control and Public Affairs Chamber. The D.C. was supposed to deal with disciplinary cases of Supreme Court judges and appeals of the disciplinary cases of judges from ordinary courts. The fact that the members of the D.C. were selected by the KRS, of which ninety-two percent of the members were elected by the Sejm, was grounds for the Commission to bring action against Poland before the CJEU in 2019. The CJEU responded to the preliminary question of the Labor and Social Insurance Chamber (LSIC) of the Polish Supreme Court on whether the D.C.'s independence and impartiality as a court was doubtful. ${ }^{130}$ The CJEU confirmed the principle of the primacy of the E.U. law and claimed that national courts had the right and had the obligation not to grant jurisdiction to a court that does not fulfill the requirements of independence and impartiality. The CJEU openly stood by the Polish judges seeking help from outside their country.

After the judgment on the preliminary question, the LSIC of the S.C. decided that the D.C. does not fulfill the requirements for being an independent and impartial court. ${ }^{131}$ Despite this decision, the D.C. kept deciding on disciplinary matters, leading the European Commission to bring action against Poland to the CJEU, seeking:

[S] uspending, the provisions constituting the basis of the competence of the Disciplinary Chamber of the Supreme Court to rule, both at first instance and on appeal in disciplinary cases relating to judges, and refrain from transferring cases pending before the Disciplinary Chamber to a formation of the court which does not satisfy the requirements of independence. ${ }^{132}$

\section{Ordinary Courts}

The ordinary courts were not exempt from PiS modifications. The retirement age of the ordinary courts' judges and the retirement age of the prosecutors was newly set to sixty-five years for male and sixty years for female judges. The previous law on ordinary courts stipulated the age limit to be sixtyseven. ${ }^{133}$ The new law also gave the justice minister power to decide on extending a term. ${ }^{134}$

As with the Supreme Court case, the European Commission brought actions before the CJEU for a failure to fulfill obligations. Moreover, in a similar situation to the case of the S.C., the CJEU concluded that the provision on various retirement ages constituted discrimination, as well as a failure to provide sufficient remedies to ensure compliance with the right to effective judicial protection in areas covered by E.U. law. ${ }^{135}$

\footnotetext{
${ }^{129}$ See Hans Petter Graver, Jussens Helter (2020).

${ }^{130}$ See EJC Joined Cases C-585/18, C-624/18 \& C-625/18, A. K. and Others v. Sąd Najwyższy, ECLI:EU:C:2019:982 Judgment of 19 Nov. 2019.

${ }^{131}$ See III PK 7/18, Judgment of the Supreme Court, OSNP 2019/9/110, https://sip.lex.pl/orzeczenia-i-pisma-urzedowe/ orzeczenia-sadow/iii-pk-7-18-wyrok-sadu-najwyzszego-522708241 (Pol.).

${ }^{132}$ See European Commission v. Republic of Poland, supra note 127.

${ }^{133}$ See Law from July 12, 2017, (noting that art. 69(1) of the Law on the ordinary courts was amended, first of all, by the ustawa o zmianie ustawy o emeryturach i rentach z Funduszu Ubezpieczeń Społecznych oraz niektórych innych ustaw [Law amending the Law on retirement pensions and other pensions payable from the Social Security Fund and certain other laws of November 16, 2016] (Dz. U. 2017.38; "the Law of 16 November 2016"), which lowered the retirement age of both female and male judges to 65 years. That amendment was to enter into force on 1 October 2017. However, before that amendment even entered into force, Article 69(1) was further amended by Article 13(1) of the Amending Law of July 12, 2017, an enactment which entered into force on 1 October 2017. As a result of that amendment, a judge's retirement age was set at 60 years for women and 65 years for men.).

${ }^{134}$ See Article 1(26)(b)-(c) of the Law amending the Law on the System of Ordinary Courts and Certain Other Laws of July 12, 2017 (Pol.).

${ }^{135}$ See Case C-192/18, European Commission v. Republic of Poland, ECLI:EU:C:2019:924 (Nov. 5, 2019).
} 
As of 2016, the justice minister ${ }^{136}$ also holds the position of the public prosecutor general, and this superposition's strength ${ }^{137}$ raised concerns. Behind the claim of further accountability of the Public Prosecutor's Office might easily be a goal of exerting political influence over public prosecutors. ${ }^{138}$ The justice minister was also granted the power to dismiss the presidents of lower courts and appoint his own chosen candidates. He received the power to assign new judges, to establish divisions and branch divisions of courts, to establish or abolish courts, to determine territorial competency areas, to authorize transfers of judges to other courts or reassignments to other state institutions, to request disciplinary proceedings against a judge, and to launch an appeal against decisions of a disciplinary court. ${ }^{139}$ The justice minister dismissed nearly 160 presidents and vice presidents. A powerful card was put in the hands of the prosecutor gen$\mathrm{eral} / \mathrm{minister}$ in the form of an institution called an extraordinary appeal, which is a judicial review of final decisions, including decisions issued before the validity of the law. The claimed goal of this institution is to "ensure compliance with the rule of law." ${ }^{140}$ It gave the justice minister the power to reopen any case decided in the last twenty years. ${ }^{141}$

If the KRS and Supreme Court reform and the court-packing throughout all the ordinary courts would leave some areas untouched, the next step subordinated the lower courts completely in administrative matters. On December 19,2019, the ruling majority approved an amendment on the law on Supreme Court and law on ordinary courts, in what became known as the Muzzle Law. ${ }^{142}$ Based on this amendment, disciplinary proceedings can be started against judges who resisted the changes of the judiciary. The amendment bans criticism from a judge that might represent "undermining the principles of the functioning of the authorities of the Republic of Poland and its constitutional organs." 143 This amendment also gives the president power to choose and appoint the first president of the S.C. ${ }^{144}$ In 2020 the majority of S.C. judges supported Włodzimierz Wróbel, but President Duda appointed Małgorzata Manowská, a judge he had nominated to the S.C. to take over the office at the request of KRS. ${ }^{145}$

Since the reforms enacted in 2017 and, finally, with the adoption of the Muzzle Law amendment, Poland might be considered a country lacking an independent judiciary. ${ }^{146}$ The Venice

\footnotetext{
${ }^{136}$ See Act on the Public Prosecutor's Office of 28 January 2016, J.L. 2016, Item 177 (Adopted by the Sejm on January 28, 2016, by the Senate on January 30, 2016, signed by the President February 12, 2016, and entered into force on March 4, 2016).

${ }^{137}$ See Venice Commission, Poland, Opinion on the Act on the Public Prosecutor's Office, DL-AD(2017)028 (Dec. 11, 2017), https://www.venice.coe.int/webforms/documents/default.aspx?pdffile=CDL-AD(2017)028-e.

${ }^{138}$ See id.

${ }^{139}$ See Wojciech Sadurski, How Democracy Dies (in Poland): A Case Study of Anti-Constitutional Populist Backsliding, 1 Revista Forumul Judecatorilor 104, 147 (2018) (detailing this statute, signed by the President on July 24, 2017).

${ }^{140}$ See Marek Tatala, Eliza Rutynowka \& Patryk Wachowiec, Rule of LaW in Poland 2020: A Diagnosis of the Deterioration of the Rule of Law from a Comparative Perspective 21 (2020).

${ }^{141}$ See Art. 115, $\$ 1$ of the Act on the Supreme Court (Dec. 8, 2017). See also Venice Commission, Poland, Opinion on the Draft Act Amending the Act on the National Council of the Judiciary, on the Draft Act Amending the Act on the Supreme Court, Proposed by the President of Poland, and on the Act on the Organisation of Ordinary Courts, CDL-AD(2017)031, para. 53 (Dec. 11, 2017), https://www.venice.coe.int/webforms/documents/default.aspx?pdffile=CDL-AD(2017)031-e.

${ }^{142}$ See Bill Amending the Act on the Organization of Ordinary Courts, the Act on the Supreme Court and the Act on the National Council of the Judiciary of Dec. 20, 2019 (Pol.).

${ }^{143}$ See Amendments from 20 December 2019 on the Act of 27 July 2001 Law on the Organisation of Common Courts, Article 9(d) (Showing that the subject of the deliberations of the college and judicial self-government may not be political matters, in particular, it is prohibited to adopt resolutions undermining the principles of functioning of the authorities of the Republic of Poland and its constitutional bodies). See also Amendments to the Act on the System of Common Courts, the Act on the Supreme Court, the Act on Supreme Court, the Act on the National Council of the Judiciary and certain other acts of Dec. 20, 2019, CDL-REF(2020)002.

${ }^{144} \mathrm{He}$ or she is elected from among the judges of the Supreme Court by the President of the Republic of Poland, if, under the provisions of the Act on the SC, 5 candidates for the new First President of the Supreme Court-elected by the General Assembly of the Supreme Court-are not presented to the President by the General Assembly.

${ }^{145}$ Tatała, Rutynowka \& Wachowiec, supra note 140.

${ }^{146}$ See Laurent Pech, Patryk Wachowiec \& Dariusz Mazur, Poland's Rule of Law Breakdown: A Five-Year Assessment of EU's (In) Action, 13 Hague J. Rule L. 1, 3 (2021) (citing Pawel Marciz, Discipline and Punish: New Polish Reforms of the Judiciary,
} 
Commission commented that the amendment was responsible for "seriously curtailing freedom of speech and association of judges, preventing judges from examining whether other courts within the country are 'independent and impartial' under the European rules."147

Despite the international criticism, the Polish judiciary, once regarded as among the most stable and most effective in the region, remains under siege. On the one hand, the constitutional framework has not been changed, as was done in Hungary, and vigorous resistance still exists among judges. On the other hand, it reminds one that "[Kaczynski's Poland will be in five years Orbán's state] because [Orbán] ruled Hungary that much longer than PiS [in Poland]."148

\section{Hungary}

The systemic attack on judicial independence in Hungary has been even more profound than in Poland. Armed with a supermajority in parliament, the government has undertaken to amend the constitution. ${ }^{149}$ There is almost no opposition in Hungary, unlike in Poland, where it is still vibrant. ${ }^{150}$ Moreover, the influence of oligarchs is much more substantial in Hungary. ${ }^{151}$

In Hungary, the systemic attack on judicial independence was, in part, also a public relations attack. On the 150th anniversary of the Hungarian parliament's enactment of a law protecting judicial independence, Speaker of the Parliament László Kövér delivered a shocking keynote address. He began by saying that "150 years ago the question was whether the Hungarian state wants to guarantee the independence of the judges. Today the question is whether the Hungarian judges want to ensure the independence of the state." 152

Judicial independence in Hungary has raised the attention of the E.U. and COE institutions since 2010, ${ }^{153}$ and it has continued to be a painful matter for the rule of law ambitions in the E.U. ever since. The situation in Hungary is shaped by the results of the last three parliamentary elections, which took place in 2010, 2014, and 2018, when the political party Fidesz and KDNP (Christian Democratic People's Party) received enough votes to adopt a new constitution that

Verfassungsblog: On Matters Constitutional (Dec. 22, 2019), https://verfassungsblog.de/discipline-and-punish, ("'blatantly unconstitutional' in addition to being flagrantly contrary to EU law.").

${ }^{147}$ See Venice Commission, Poland, Joint Urgent Opinion of the Venice Commission and the Directorate General of Human Rights and Rule of Law (DGI) of the Council of Europe on amendments to the Law on the Common courts, the Law on the Supreme court and some other Laws, CDL-AD(2020)017 of Jan. 16, 2020, para. 59, https://www.venice.coe.int/webforms/ documents/?pdf=CDL-PI(2020)002-e.

${ }^{148}$ See Sadurski, supra note 139 , at 107.

${ }^{149}$ See, e.g., Hungary: Democracy under Threat, InTERnAtional Federation of Human Rights (Nov. 2016), https://www. fidh.org/IMG/pdf/hungary_democracy_under_threat.pdf; Eva S. Balogh, Soon Enough, Hungarian Judicial Independence Will Exist Only in History Books, Hungarian SPECTRUM (Apr. 24, 2019), https://hungarianspectrum.org/2019/04/24/soonenough-hungarian-judicial-independence-will-exist-only-in-history-books/.

${ }^{150}$ Tímea Drinóczi \& Agnieszka Bień-Kacala, Illiberal Constitutionalism: The Case of Hungary and Poland, 20 GERMAN L.J. 1140, 1142 (2019).

${ }^{151}$ See Bálint Magyar, Post-Communist Mafia State. The Hungarian Case (2016).

${ }^{152}$ See Balogh, supra note 149 , at 1.

${ }^{153}$ See, e.g., Kovács \& Scheppele, supra note 105; Hungary: Legislative Changes Threaten Democracy and Human Rights, COMMISSIONER FOR HUMAN RIGHTS, https://www.coe.int/en/web/commissioner/view/-/asset_publisher/ugj3i6qSEkhZ/content/ hungary-legislative-changes-threaten-democracy-and-human-rights (last visited May 25, 2021); European Commission launches accelerated infringement proceedings against Hungary over the independence of its central bank and data protection authorities as well as over measures affecting the judiciary, EUROPEAN COMMISsION, https:/lec.europa.eu/commission/presscorner/detail/en/IP_ 12_24 (last visited May 25, 2021) (Noting accelerated infringement proceeding against Hungary over lowering the mandatory retirement age for judges, prosecutors and public notaries); Venice Commission, Hungary, Opinion on the Cardinal Acts on the Judiciary That Were Amended Following the Adoption of Opinion, CDL-AD (2012) 001, CDL-AD(2012)(020) (Oct. 15, 2012), https://www.venice.coe.int/webforms/documents/default.aspx?pdffile=CDL-AD(2012)020-e (Showing up to the Article 7(1) TEU procedure initiated by the European Parliament. Proposal for a Council Decision on the determination of a clear risk of a serious breach by Hungary of the rule of law. European Parliament resolution of September 12, 2018 on a proposal calling on the Council to determine, pursuant to Article 7(1) of the Treaty on European Union, the existence of a clear risk of a serious breach by Hungary of the values on which the Union is founded (2017/2131(INL)). 
amends the institutional structure in Hungary. Unlike in Poland, in Hungary it was possible to start with the changes on the constitutional level, which enabled the parties in power to pass amendments smoothly. With a two-thirds majority, Prime Minister Viktor Orbán could create a new structure to support his concept of the "illiberal democracy." 154

\section{New Constitution}

Just one year into its term, the governing coalition amended its inherited constitution twelve times. ${ }^{155}$ Finally, on April 18, 2011, the National Assembly of the Hungarian Republic adopted a new constitution - the Fundamental Law of Hungary. This step might not have been viewed with alarm. The Hungarian People's Republic adopted the previous constitution in 1949, ${ }^{156}$ and Hungary was the last country of the CEE to have not created a new constitution after the fall of communism.

Nevertheless, the constitution-making process was criticized ${ }^{157}$ for lack of transparency, omission of civil society from discussions, shortcomings in the dialogue between the majority and the opposition, insufficient opportunities for public debate, and extremely short timeframe for creation. ${ }^{158}$ What raised the concerns of the Venice Commission in 2011 was the number of matters relegated to regulation via cardinal laws, ${ }^{159}$ including issues that do not need such rigidity and should be left for a simple majority political process. ${ }^{160}$ These cardinal laws could lead to "carving in stone" due to their difficult amenability and impossibility of constitutional review.

The structure of the justice system was amended dramatically. For this Article's purposes, we will present the primary sources and mechanisms of this change. We will focus on three avenues, each of which is connected to the new Fundamental Law and related legislation. The first was a change of framework for the Constitutional Court. The second was the change in personnel and normative framework of the Supreme Court and general courts, and the third was the change in the courts' administration.

\section{Limitation of the Constitutional Court}

Hungary has a unicameral system, with the Constitutional Court as the most potent check in the constitutional structure. ${ }^{161}$ Three strategies were followed to limit the Constitutional Court (CC). The first was limiting on what the $\mathrm{CC}$ cannot decide or what cannot be referenced in decision-making. Second, a court-packing strategy was used to amend the personnel composition of the CC. ${ }^{162}$ Third, commands were set out to order what must be taken into account by the $\mathrm{CC}$ in its decision-making.

The Constitutional Court is limited in referring to its own case law dated prior to January 1, 2012. This strategy of limiting the CC in its decision-making is visible in the fifth paragraph of the closing provisions of the Fundamental Law: "The decisions of the Constitutional Court made before the entry into force of the Fundamental Law are repealed. This provision shall be without

\footnotetext{
${ }^{154}$ See Tímea Drinóczi \& Agnieszka Bień-Kacala, supra note 150. For the concept of illiberal democracy, see Fareed Zakaria, The Rise of Illiberal Democracy, 76 ForeIGN AfF. 22 (1997); Bojan Bugarič \& Tom Ginsburg, The Assault on Postcommunist Courts, 27 J. OF Democracy 69, 73-75 (2016).

${ }^{155}$ See Kovács \& Scheppele, supra note 105, at 191.

${ }^{156}$ Although it was heavily amended in 1989.

${ }^{157}$ See Venice Commission, Hungary, Opinion on the New Constitution of Hungary, CDL-AD (2011) 016 Or (Jun. 20, 2011), https://www.venice.coe.int/webforms/documents/default.aspx?pdffile=CDL-AD(2011)016-e.

${ }^{158}$ See $I d$. at para. 144.

${ }^{159}$ On Cardinal laws, see Mauro Mazza, The Hungarian Fundamental Law, the New Cardinal Laws and European Concerns, 54 ACTA JURIDICA HUNGARICA 140 (2013) (Also noting existence of organic laws, the approval of which requires the majority of two thirds of the votes cast by members present in the Parliament).

${ }^{160}$ For examples of cultural, religious, moral, socio-economic and financial policies, see Venice Commission, Hungary, Opinion on the New Constitution of Hungary, CDL-AD (2011) 016 Or (Jun. 20, 2011), para. 145, https://www.venice.coe. int/webforms/documents/default.aspx?pdffile=CDL-AD(2011)016-e.

${ }^{161}$ Kovács \& Scheppele, supra note 105 , at 191.

${ }^{162}$ For court-packing strategies, see Kosar \& Sipulova, supra note 104.
} 
prejudice to the legal effects produced by those decisions." 163 This fresh start provision made the previous decisions irrelevant for future decision-making and, therefore, the argument by the CC of following any kind of precedent was invalidated. As a result, the CC could decide on a fresh plane in matters of conflict of legislation with the Constitution.

This provision does not ban the use of the same arguments ${ }^{164}$ as those used in the past, but when accompanied by new judges favoring the interpretation of discontinuity from the old constitution or just favorable to Viktor Orbán, the CC has a solid defense to not be bound by previous case law. Such a strategy of liberating the CC from its history is very effective when combined with a court-packing strategy. In addition to the normative starting point of being free from referencing previous case law, the $\mathrm{CC}$ also has judges who are themselves willing to depart from previous case law.

The option of constitutional review of the constitutional acts was in Hungary a marginal question for long years. ${ }^{165}$ Hungarian CC stuck to the doctrine that it does not review the constitutionality of amendments to the Constitution:

Due to the close connection between the provision putting the amendment of the Constitution into force with immediate effect and the provisions that become the normative text of the Constitution as a result of such amendment, the Constitutional Court can't examine the constitutionality of the provision putting the amendment of the Constitution into force, as it would result in the Constitutional Court exceeding its constitutional scope of competence institutionalized for safeguarding the Constitution, and taking over the scope of the authority of establishing the Constitution, thus it would not only interpret the provisions of the Constitution but necessarily qualify them as well." 166 The constitution-making competence supposedly belonged to the National Assembly. In 2012 the CC changed this tradition, deciding, "The Constitutional Court's obligation to protect the Fundamental Law includes the duty of protecting it as a single and unified document with the normative contents and structure as adopted by the constituent power: as a single and unified legal document, making it unquestionable and stable for everyone. "167 The disapproving reaction from the parliament was swift. In 2013, the Fourth Amendment to the Fundamental Law limited the review of the CC to "the procedural requirements laid down in the Fundamental Law for making and promulgating it." 68

Furthermore, the CC's jurisdiction is connected to the country's financial situation. The CC is restricted in the review of the Acts on central budget, central taxes, pensions, healthcare contributions, the right to life and human dignity, the right to the protection of personal data, freedom of thought, conscience and religion, and rights related to Hungarian citizenship if at any point the government debt exceeds half of the total gross domestic product. ${ }^{169}$ Before the

\footnotetext{
${ }^{163}$ Hungarian Fundamental Law, Closing Provisions, para. 5 (Apr. 25, 2011).

${ }^{164}$ Alkotmánybír'oság (AB) [Constitutional Court] Decision 22/2012. (V. 11.) (interpreting para. (2)-(4) of Art. (E) of the Fundamental Law (V. 11.), para. 40) (Hung.) (Noting that, in the new cases the Constitutional Court may use the arguments included in its previous decision adopted before the Fundamental Law came into force in relation to the constitutional question ruled upon in the given decision, provided that this is possible on the basis of the concrete provisions and interpretation rules of the Fundamental Law, having the same or similar content as the provisions included in the previous Constitution).

${ }^{165}$ Zsuzsa Szakály, Two Sides of The Same Coin: Internal and External Protection of the Material Core of the ConstitutionThe Eternity Clauses as the Internal Protection, in ZBORNík Z MEDZINÁRODNEJ VEDECKEJ KONFERENCIE: BRATISLAVSKÉ PRÁVNICKÉ FÓRUM 2020, 14 (Feb. 2020).

${ }^{166}$ Alkotmánybír'oság (AB) [Constitutional Court] Decision 1260/B/1997 (Hung.).

${ }^{167}$ Alkotmánybír'oság (AB) [Constitutional Court] Decision 45/2012. (XII. 29.) (Hung.).

${ }^{168}$ Hungarian Fundamental Law art. 24, para. 5.

${ }^{169}$ Hungarian Fundamental LAW art. 37, para. 4.
} 
public debt falls below fifty percent of GDP, ${ }^{170}$ the CC will not decide on compliance of these Acts with Fundamental law. ${ }^{171}$

Court-packing was initiated even before the Fundamental Law came to force. In 2011 the original number of judges of the CC increased from eleven to fifteen, ${ }^{172}$ with four new judges elected by a two-thirds majority of the new government in the National Assembly. In addition, the term of the judges was extended from nine to twelve years, and the retirement age of seventy was abolished. In 2013, eleven out of fifteen judges had been nominated by the ruling coalition of Fidesz-KDNP.

The third strategy was primarily directed toward the general courts, although it affected the CC significantly. In 2018 the National Assembly adopted the Seventh Amendment to the Fundamental Law of Hungary. In addition to creating administrative courts, the amendment also stated that the starting point for judges interpreting the law has to be an explanatory memorandum attached to legislative proposals:

In the course of the application of the law, courts shall interpret the text of laws primarily in accordance with their purpose and with the Fundamental Law. In the course of ascertaining the purpose of a law, consideration shall be given primarily to the preamble of that law and the justification of the proposal for, or for amending, the law. When interpreting the Fundamental Law or laws, it shall be presumed that they serve moral and economic purposes which are in accordance with common sense and the public good. ${ }^{173}$

Issuing binding and politically interpretative guidance to judges fails to insulate them from the politics of the legislature and, thus, presents a significant threat to their independence and impartiality. This measure also reduces the independence of judicial decision-making by restricting judges' discretion in interpreting the law. Furthermore, the reasoning is prepared by a competent minister or even an individual M.P. and is not part of the law, so it is not a normative act and cannot be subject to constitutional review. Consequently, the governing majority can instruct judges to interpret a law with regard to a political aim that could even be unconstitutional." 174

This duty for the ordinary courts puts the CC in a position of deciding on a general court's decision that is supported with explanatory provisions excluded from constitutional review. Thus, the CC becomes subordinate to the will of the legislator.

\section{Kúria and Ordinary Courts}

The second in line for dramatic change was the Supreme Court, which reverted to an older name, Kúria, and received a new normative and personnel framework. The strategy for court-packing applied here was opposite that used for the CC. Instead of the age limit being removed, it was lowered. Moreover, rather than bringing in additional judges, the strategy was to dismiss the previous judges before the new ones arrived. The lowering of the age limit from seventy

\footnotetext{
${ }^{170}$ Euro Area and EU27 Government Deficit Both at 0.6\% of GDP, EUROSTAT, https://ec.europa.eu/eurostat/documents/ 2995521/10294648/2-22042020-AP-EN.pdf (2020) (Showing that, in 2019, the debt was 66.3 percent, and, in 2010, it was more than eighty percent). See also Structure of Government Debt in Europe in 2010, EuROSTAT, https://ec.europa.eu/eurostat/ documents/3433488/5580012/KS-SF-11-068-EN.PDF.pdf/b6702d03-bed8-416a-9879-732564dcb08e?t=1414693427000 (2011).

${ }^{171}$ See Lajos Meszaros, Aktuálne otázky nezávislosti justície v Madarsku, in NEZAVISLOST SOUDNI MOCI, at 123 (Vojtech Šimíček, ed. 2020).

${ }^{172}$ See Act CLI of 2011 on the Constitutional Court, $\$ 7$, para. 1.

${ }^{173}$ See Hungarian Fundamental Law, art. 28. See also Gábor Halmai, A Coup Against Constitutional Democracy: The Case of Hungary, CONSTITUTIONAL Democracy In CRIsis 240 (2018).

${ }^{174}$ Hungarian Helsinki Committee, Independence of the Judiciary Under Attack in Hungary, ORGANIZATION FOR SECURITY AND CO-OPERATION IN EUROPE (Sept. 12, 2018), https://www.osce.org/odihr/393824.
} 
to sixty-two ${ }^{175}$ caused an exodus of a large number of judges. ${ }^{176}$ The fact that the age limit for judges was decided to be invalid by the $\mathrm{CC},{ }^{177}$ did not stop the reform from succeeding in its intention. In 2013 the amendment of the Act CLXII of $2011^{178}$ allowed judges to seek compensation or reinstatement, but many of judges dismissed from Kúria were either unwilling to return or had already passed the age of seventy by the time the CJEU had released its decision. ${ }^{179}$ The reform resulted in only a few judicial administrative leaders over the age of sixty-two left in the judiciary after 2012. ${ }^{180}$

A well-known example is the former President of the Supreme Court András Baka, ${ }^{181}$ who was dismissed from the position of the president when the new Fundamental Law came to force. ${ }^{182}$ Furthermore, he could not apply for the position, as he did not fulfill the requirement of serving at least five years as a judge in Hungary. Baka had been a judge of the European Court of Human Rights for seventeen years. The requirement of the five-year term served at a court in Hungary could be perceived as retaliation against Baka for his criticism of the steps of the government toward the judiciary, which was part of his job as the president of the S.C. ${ }^{183}$

\section{Courts' Administration}

Finally, the third manner of attacking the third branch was through the courts' administration. For the strategy of court-packing the Kúria and general courts, it was crucial to control the selection and appointment of new judges, as the old judges were forced out due to the lowered age limit. This part of the chain was supposed to be filled with the president of the National Judicial Office (NJO), which was established by Parliament in $2012^{184}$ as a one-person decision-making body for

\footnotetext{
${ }^{175}$ See Case C-286/12, Comm'n v. Hungary (Nov. 6, 2012) (“Declar[ing] that, by adopting a national scheme requiring compulsory retirement of judges, prosecutors and notaries when they reach the age of 62 - which gives rise to a difference in treatment on grounds of age which is not proportionate as regards the objectives pursue.").

${ }^{176}$ See The Act on the Transitional Provisions of the Fundamental Law (2011) art. 11. (Noting that, more specifically, the new maximum retirement age rules led to the de facto dismissal of 20 out of 74 Supreme Court judges) (Hung.). See also David Kosař \& Katarína Šipulová, The Strasbourg Court Meets Abusive Constitutionalism: Baka v. Hungary and the Rule of Law, 10 Hague J. Rule L. 83 (2018); Kovács \& Scheppele, supra note 105, at 192 (“The vast majority of senior judges-between ten and fifteen percent of all judges in the country, and disproportionately including judges in the leadership of the courts - were forced to leave the bench almost immediately."). European Comm'n, European Commission Launches Accelerated Infringement Proceedings against Hungary Over the Independence of its Central Bank and Data Protection Authorities as well as Over Measures Affecting the Judiciary, https://ec.europa.eu/commission/presscorner/detail/en/IP_12_24 (Jan. 17, 2012) (Noting accelerated infringement proceeding was started by the European Commission for the independence of its central bank and data protection authorities as well as over measures affecting the judiciary).

${ }^{177}$ See Alkotmánybíróság (AB) [Constitutional Court], MK. 33/2012, VII. 17 (Hung.).

${ }^{178}$ See Act XX of 2013. (Hung.).

${ }^{179}$ See Alkotmánybíróság (AB) [Constitutional Court], MK. 33/2012, VII. 17 (Hung.) (Showing that, in 2012, the Constitutional Court ruled, before the international criticism from CJEU, the provisions of the Law on the Legal Status and Remuneration of Judges that lowered the mandatory retirement age of judges to the general retirement age as of January 1, 2012 are unconstitutional). See also CJEU, Case C-286/12, Comm'n v. Hungary, ECLI:EU:C:2012:687 (Nov. 6, 2012) ("Declares that, by adopting a national scheme requiring compulsory retirement of judges, prosecutors and notaries when they reach the age of 62 - which gives rise to a difference in treatment on grounds of age which is not proportionate as regards the objectives pursue.").

${ }^{180}$ See Meszaros, supra note 171 , at 125 .

${ }^{181}$ Baka v. Hungary, App. No. 20261/12 (June 23, 2016), https://hudoc.echr.coe.int/eng\#\{\%22appno\%22:[\%2220261/12\% $22]\}$.

${ }^{182}$ The Act on the Transitional Provisions of the Fundamental Law, art. 11, para. 2 (2011) (Hung.).

${ }^{183}$ See Kosař \& Šipulová, supra note 176, at FT.54 (stating that Baka lodged an application with ECtHR for his "mandate has been terminated as a result of the views and positions that he had expressed publicly in his capacity as President of the Supreme Court concerning legislative reforms affecting the judiciary, which is a violation of his freedom of expression."). This constitutional amendment was adopted only on November 29, 2011 and came into force on December 2, 2011, that was a few days before the election of the new Supreme Court President.

${ }^{184}$ See Act CLXI of 2011 on the Organisation and Administration of Courts (Hung.).
} 
matters of recruitment, promotion, management of the court budgets, and disciplinary matters. ${ }^{185}$ The body elected by judges - National Council of Judiciary-lacked any significant power, and the power of the NJO was criticized as unbalanced due to the strong position of the NJO towards judges. ${ }^{186}$ The position of the President of the NJO received international criticism. It was seen as a "crucial decision-maker of practically every aspect of the organization of the judicial system and he or she has wide discretionary powers that are mostly not subject to judicial control." The NJO cannot be perceived as body of judicial self-government, for its members are elected by the National Assembly. ${ }^{187}$

The unbalanced power over judges, mainly through the appointment of the court presidents and the ability to transfer cases ${ }^{188}$ or regulate judges' early retirement, became a target of objections. The initial criticism from international bodies encouraged the Parliament to move the NJO to the constitutional level. ${ }^{189}$

In September 2013 the Parliament moved to restrict the president of the NJO in his power and put the office under supervision of the NCJ. However, this happened after "the storm," which had begun twenty months earlier in January 2012. The changes on the national level in reaction to international objections became even more controversial than before, as they became part of the Fundamental Law, ${ }^{190}$ like the change in the transferring of cases by the president of the NJO. ${ }^{191}$ Even though the power of the NJO was nominally limited, the real power was

\footnotetext{
${ }^{185}$ See Hungarian Fundamental Law, art. 25, para. 5. See also Letter from the Commissioner for Human Rights, to Janos Martonyi, Minister for Foreign Affairs of the Republic of Hungary, https://rm.coe.int/16806db8b1 (Dec. 16, 2011) (Noting that initial concerns were conveyed already in 2011 by the Commissioner for Human Rights); Commissioner for Human Rights, Hungary: Legislative Changes Threaten Democracy and Human Rights, COUNCIL OF EUROPE, (Dec. 1, 2012) https://www.coe.int/en/web/commissioner/-/hungary-legislative-changes-threaten-democracy-and-humanrights. The Venice Commission also sent their concerns in March 2012 about the power of the President of the NJO. See Venice Commission, Hungary, Opinion on Act CLXII of 2011 on the Legal Status and Remuneration of Judges and Act CLXI of 2011 on the Organisation and Administration of Courts, para. 118 (Mar. 19, 2012), https://www.venice.coe.int/ webforms/documents/default.aspx?pdffile=CDL-AD(2012)001-e (criticizing the position of the NJO for having "crucial decision-maker in practically every aspect of the organization of the judicial system").

${ }^{186}$ See Venice Commission, Opinion on Act CLXII of 2011 on the Legal Status and Remuneration of Judges and Act CLXI of 2011 on the Organisation and Administration of Courts of Hungary, COUNCIL OF EUROPE, Opinion No. 663/2012, para. 118 (Mar. 19, 2012), https://www.venice.coe.int/webforms/documents/default.aspx?pdffile=CDL-AD(2012)001-e (In which the position of the NJO was criticized for having "crucial decision-maker in practically every aspect of the organization of the judicial system.").

${ }^{187}$ See Id. at para. 42.

${ }^{188}$ This power was later abolished when Act CXXXI of 2013, which abolished the NJO President's right to transfer cases from one court to another, entered into force.

${ }^{189}$ See Eötvös Karoly Policy Institute, Main Concerns Regarding the Fourth Amendment to the Fundamental Law of Hungary, at 4-5 (Feb. 26, 2013) (Noting that the right to reassign cases in Act CLXI of 2011 on the Organization and Administration of Courts was based on Article 11 (3) of the Transitional Provisions of the Fundamental Law, which states that the President of the NJO may execute its power to reassign cases "until a balanced distribution of caseload between courts has been realized." This rule of the Transitional Provisions was also abolished by the CC in its Decision 45/2012. (XII. 29.), because it was not considered as a transitional provision in character. However, the Fourth Amendment of Fundamental law upholds the NJO President's right to transfer cases, but also abolishes the transitional character of the system of transferring cases. This move is in clear contradiction with the standpoint of the Venice Commission, and aggravates the violation of the principle to a lawful judge).

${ }^{190}$ See National Judicial Council, Report by the Committee Established by NJC Decision 101/2018 (X.03.) to Review the Practice Adopted by the President of the NOJ During the Evaluation of Applications for Single Judge and Court Management Positions and the President's Performance of its Obligations in Respect of the NJC (Jan. 28, 2019) (Hung.).

${ }^{191}$ Compare Original Transitional Provisions, art. 11, para. 3 ("In the interest of the enforcement of the fundamental right to a court decision within a reasonable time as provided in Article XXVIII (1) of the Fundamental Law, until a balanced distribution of caseload between courts has been realized, the President of the National Judicial Office may designate a court other than the court of general competence but with the same jurisdiction to adjudicate any case"); with The Act on the Transitional Provisions of the Fundamental Law (2011) art. 27, para. 4 ("In the interest of the enforcement of the fundamental right to a court decision within a reasonable time and a balanced distribution of caseload between the courts, the President of
} 
maintained. ${ }^{192}$ The factual position of the president of the NJO keeps creating tension towards the judiciary, especially to the NJC, and in recent years it has led to a "constitutional crisis."193

Despite facing intense criticism from judges, the judicial association and the NJC, the President of the NJO Tünde Handó, became a judge of the CC in 2020, replacing István Stumpf, the last member of the CC who had been appointed before the election of Orban. ${ }^{194}$

Such a structural change in the justice system achieved the intended outcomes. The successful application of Baka does not change the situation in the Hungarian national context. In the same way, as the judges dismissed following the enactment of new age limits were successful at the CC but not guaranteed their position at the courts, in Baka's case again, the intention of the parliamentary majority was successful. Nevertheless, Hungary still experiences some dissent against political interference in the judiciary. The NJC clashed with the President of the NJO in 2018, which resulted in significant resistance by members of the NJC. NJC member Csaba Vasvári turned to the CJEU with a preliminary question on judicial independence in Hungary. ${ }^{195}$ Subsequently, the Kuria claimed the preliminary question from the CJEU was unlawful, ${ }^{196}$ and the regional court president filed a motion for disciplinary proceedings against Vasvári. With this example and the punishing of the former President of the Supreme Court Baka, the judiciary's growing activism to ensure that its members not be punished for fulfilling their duties and not be subordinated below political actors. Moreover, because of strong resistance from the judges, the public, and the international community against the influence of the justice minister on the new administrative courts, ${ }^{197}$ the plan to establish an administrative judiciary in 2020 was abandoned. ${ }^{198}$

the National Judicial Office may designate a court, for cases defined in a cardinal Act and in a manner defined also in a cardinal Act, other than the court of general competence but with the same jurisdiction to adjudicate the case.") (Hung.).

${ }^{192}$ See Fourth Evaluation Round, Hungary, at para. 97, CounCIL OF Europe, Group OF STATES AGAINST CORRUPTION (GRECO), https://rm.coe.int/fourth-evaluation-round-corruption-prevention-in-respect-of-members-of/1680969483 (2019):

$[\mathrm{N}]$ o progress has been made to review the powers of the president of the NJO in the selection of candidates and strengthen those of the NJC accordingly, to reduce the legal powers to re-assign judges without their consent and to limit the immunity of judges to activities related to their participation in the exercise of justice.

${ }^{193}$ See European Association of Judges, Report on the Fact-Finding Mission of the EAJ to Hungary, MAGYARORSZAG BIROSAGAI, https://birosag.hu/sites/default/files/users/2019.05.17_Report\%20EAJ\%20Hungary.pdf (Aug. 2019). Since May 2018 the Hungarian Judiciary is facing a very grievous situation which in some aspects comes close to a "constitutional crisis" due to the activity of the President of the NOJ who denies any collaboration with the National Judicial Council. Thus, the two bodies of judicial self-government, the National Office of the Judiciary (NOJ) and the National Judicial Council (NJC) cannot work together any longer which leads to a blockade, and thus to the impossibility of the NJC to perceive its supervisory tasks.

${ }^{194}$ See Kovács Zoltán, Parliament Elects Tünde Handó to the Constitutional Court and Reelects Prosecutor General Péter Polt, (Nov. 4, 2019) https://index.hu/english/2019/11/04/hungary_parliament_tunde_hando_constitutional_court_peter_polt_ prosecutor_general/.

${ }^{195}$ See ECJU, Case C-564/19, Summary of the Request for a Preliminary Ruling Pursuant to Article 98(1) of the Rules of Procedure of the Court of Justice, (2019), https://curia.europa.eu/juris/showPdf.jsf;jsessionid=D2D4B6802D6157B56B13A537B93E24BE? text $=\&$ docid $=220134 \&$ pageIndex $=0 \&$ doclang $=\mathrm{EN} \&$ mode $=$ req\&dir $=\& o c c=$ first $\&$ part $=1 \& \mathrm{cid}=4965104$.

${ }^{196}$ See Biró Marianna \& Kovács Zoltán, Request for the European Court of Justice to Examine Hungarian Judicial Independence Found Unlawful by the Curia (Nov. 9, 2019), https://index.hu/english/2019/09/11/curia_european_court_of_ justice_preliminary_ruling_judicial_independence_prosecutor_general_peter_polt/.

${ }^{197}$ See Venice Commission, Hungary, Opinion on the law of Administrative Courts and on the Law of the Entry into Force of the Law on Administrative Courts and Certain Transitional Rules, CDL-AD(2019)004 of Mar. 19, 2019, para. 113, https://www.venice.coe.int/webforms/documents/default.aspx?pdffile=CDL-AD(2019)004-e (objecting "that very extensive powers are concentrated in the hands of a few stakeholders and there are no effective checks and balances to counteract those powers"). See also Commissioner for Human Rights, Commissioner Calls on Hungary's President to Return to the Parliament the Legislative Package on Administrative Courts, https://www.coe.int/en/web/commissioner/ view/-/asset_publisher/ugj3i6qSEkhZ/content/commissioner-calls-on-hungary-s-president-to-return-to-the-parliamentthe-legislative-package-on-administrative-courts.

${ }^{198}$ See Kovács Zoltán, Hungarian Government Scraps Concept of Separate Administrative Courts, INDEX (Nov. 4, 2019), https://index.hu/english/2019/11/04/administrative_courts_scrapped/. Even though already incorporated in the Fundamental Law via Seventh Amendment in 2018. The Parliament adopted Act LXI of 2019 on Postponing the Entry into Force of the Act on Administrative Courts, which prevents Act CXXX of 2018 on Administrative Courts. At this moment the intention of establishing the administrative courts has been stopped. 


\section{E. The Insidious Attack}

\section{United States}

In the U.S. context, we will discuss a particular kind of attack we call the insidious. Therefore, we will omit discussion of court-packing ${ }^{199}$ proposals that would create a systemic attack in our categorization. Due to the specific quality of rhetoric from political actors, we will refer mainly to statements and publicly expressed opinions.

During the presidential term of Donald Trump, the attacks were no more subtle but have taken a far different and more insidious form. ${ }^{200}$ Instead of directly approaching a sitting judge about a particular case, Trump has publicly identified judges as if they belong to him — "my judges"—or as if they belong to a predecessor president who nominated them - "Obama's judge". ${ }^{201}$ Further, judges deciding particular cases of interest to Trump have been derided as, for example, a "Mexican judge." 202 In this particular instance, the judge was of Mexican descent, and because Trump has called Mexicans "rapists" and because Trump so prominently insisted on building a wall to prevent border crossings by Latin Americans coming from Mexican territory to U.S. territory, Trump's reasoning is that such a judge could never be fair to him and must therefore be disqualified. ${ }^{203}$

Trump started this undermining tactic even while still a candidate. While it is not unusual for a presidential candidate to promise to appoint judges who share a world-view or philosophy with the president, the language chosen has been something like, "I promise to appoint judges who are pro-life [or who see the right to bear arms as essential to the American experience], or the like."204 Nevertheless, with Trump the language chosen even at this early stage was to describe "my judges" or "her judges," expressing ownership. Assuring Evangelical Christians that gun rights will be protected, a curious concept on its face, he said to such an audience: "If it's my judges, you know how they're gonna decide." 205 At a similar campaign-trail event, he said, "[m]y judges will be pro-life." ${ }^{206}$ Multiple such examples can easily be found.

The penchant for describing judges as a president's property continued whenever Trump lost a case decision. When for example, a federal district court judge blocked Trump's Muslim travel ban, Trump was quick to describe him as "Obama's judge." 207 The idea being communicated

\footnotetext{
${ }^{199}$ See Stephen Feldman, Court-Packing Time? Supreme Court Legitimacy and Positivity Theory, 68 BuFf. L. REV. 1519 (2020); see also Richard Mailey, Court-Packing in 2021: Pathways to Democratic Legitimacy, 44 SEATTLE U. L. ReV. 35-68 (2020).

${ }^{200}$ See Michael J. Nelson \& James L. Gibson, Has Trump Trumped the Courts, 93 NYU L. Rev. OnLINE 32 (2018).

${ }^{201}$ Katie Reilly, President Trump Escalates Attacks on 'Obama Judges' After Rebuke From Chief Justice, Time (Nov. 21, 2018), https://time.com/5461827/donald-trump-judiciary-chief-justice-john-roberts/.

${ }^{202}$ Eli Rosenburg, The Judge Trump Disparaged as 'Mexican' will Preside Over an Important Border Wall Case, WASH. POST (Feb. 5, 2018), https://www.washingtonpost.com/news/politics/wp/2018/02/05/the-judge-trump-disparaged-as-mexican-willpreside-over-an-important-border-wall-case/.

${ }^{203} I d$. (Noting that here, his tactic is strikingly similar to Štefan Harabin's, the infamous former Slovak Chair of Supreme Court and Minister of Justce, in which he creates a possible bias by a judge and then claims such a judge should not judge him. By charging a fellow judge with misconduct or publicly declaring a fellow judge to be a criminal or worse, Harabin then later claims that the judge he has attacked cannot be an impartial judge of a case involving Harabin as a party. In general, whether in lawyer or judicial ethics, disqualification principles should include the idea that one who creates a conflict of interest or impartiality challenge may not rely on it as a basis to disqualify others.).

${ }^{204}$ See Fr. Mark Hodges, Trump: 'My judges will be pro-life,' but gay marriage is 'settled law,' LifE SITE NEWs (Nov. 14, 2016), https://www.lifesitenews.com/news/trump-i-will-appoint-pro-life-justices-but-gay-marriage-is-settled-law.

${ }^{205}$ See Marc Fisher, Trump to Congress: See You in Court, WASH. Post (Apr. 26, 2019), https://www.washingtonpost.com/ politics/trump-to-congress-see-you-in-court/2019/04/26/9f114890-678d-11e9-82ba-fcfeff232e8f_story.html; See also Sarah McCammon, Inside Trump's Closed-Door Meeting, Held To Reassure 'The Evangelicals', NPR (June 1, 2016), https://www. npr.org/2016/06/21/483018976/inside-trumps-closed-door-meeting-held-to-reassures-the-evangelicals.

${ }^{206}$ See Hodges, supra note 204.

${ }^{207}$ See Reilly, supra note 201. For more perceptions of Trump's tweets on judges, see Christopher D. Kromphardt \& Michael F. Salamone, "Unpresidented!" or: What Happens When the President Attacks the Federal Judiciary on Twitter, 18 J. INF. TECHNOL. POL. 1 (2020).
} 
is straightforward: Judges simply do as the president who appointed them wants them to do; judges are not independent or impartial arbiters of law and facts; their decisions are easily predictable by knowing the president who appointed them. Two corollaries emerge. First, judges are mere political actors doing as their sponsor wishes them to do. Their decisions are essentially illegitimate. Second, if you like my policies, rejoice if I get the opportunity to appoint more judges because they will do as I tell them.

This phenomenon became commonplace in Trump's reactions to judicial decisions that frustrated his policies. These judges were not fair and impartial, they were Obama's judge or Clinton's judge, and therefore their decisions were as if directed by Obama or Clinton. ${ }^{208}$ It was so pronounced that Chief Justice Roberts took the extraordinary step of issuing a statement about judges and the presidents who appoint them: "We do not have Obama judges or Trump judges, Bush judges or Clinton judges. What we have is an extraordinary group of dedicated judges doing their level best to do equal right to those appearing before them," Roberts said. On the day before Thanksgiving, he concluded, "The independent judiciary is something we should all be thankful for." 209

Itching to continue a fight with the independent judiciary, Trump responded in another tweet: "Sorry Chief Justice John Roberts, but you do indeed have 'Obama judges,' and they have a much different point of view than the people who are charged with the safety of our country." 210 Now, "Obama judges" are not only lacking independence, they do not care about the safety of Americans.

The message is beginning to stick. More often and more prominently than before, it was usual to read in media that describes a judicial decision that Clinton appointed the judge, second Bush, Obama, Trump, or even first Bush. This idea has crept into the consciousness: Who appointed the judge matters and if a person disagrees with a judge, the explanation may simply be that the person disagreed with the president who appointed him or her. Even a recent Supreme Court Justice, Justice Thomas, has implied that this is the case in a recent opinion. ${ }^{211}$

Arguably, the worst of these comments are those attributing a judge's decision to the president who appointed the judge. Nevertheless, Trump's disparagement of judges, implying a lack of independence or impartiality, has also taken other forms. Trump is a private party in an enormous number of lawsuits. One of his frequent tactics to win a business advantage is simply to refuse payment owed under a contract and force a less-resourced plaintiff into a court battle. ${ }^{212} \mathrm{He}$ is also a defendant in multiple fraud cases, one prominent one being a lawsuit by former students at the so-called "Trump University." 213 Former students have sued for fraud. One judge presiding over the case is an American of Mexican descent. Trump asserted publicly that this judge could not be trusted to issue impartial decisions. ${ }^{214}$ In still another example, at the time, Attorney General Jeff Sessions wondered on a conservative talk radio show, why it should be that "judge sitting on an island in the Pacific can issue an order that stops the president of the United States from what appears to be clearly his statutory and constitutional power." ${ }^{215}$ The Pacific island, of

\footnotetext{
${ }^{208}$ In a parallel context not the subject of this Article, Trump repeatedly decried the Mueller investigatory team as "the angry Democrats." Never mind that Mueller was a lifelong Republican. In Trump-world, truth is irrelevant. Only his desired message matters.

${ }^{209}$ See Mark Sherman, Roberts, Trump Spar in Extraordinary Scrap over Judges, Associated PrEss (Nov. 21, 2018), https:// www.apnews.com/c4b34f9639e141069c08cf1e3deb6b84.

${ }^{210}$ See Reilly, supra note 201.

${ }^{211}$ See Washington Post Editorial Board, John Roberts Said There are no Trump Judges or Obama Judges, Clarence Thomas Didn't Get the Memo, WASH. Post (June 28, 2019), https://www.washingtonpost.com/opinions/john-roberts-said-there-are-no-trumpjudges-or-obama-judges-clarence-thomas-didnt-get-the-memo/2019/06/28/00ec5db0-99c6-11e9-8d0a-5edd7e2025b1_story.html.

${ }^{212}$ See Alexandra Berzon, Donald Trump’s Business Plan Left a Trail of Unpaid Bills, WaLL ST. J. (June 9, 2016), https:// www.wsj.com/articles/donald-trumps-business-plan-left-a-trail-of-unpaid-bills-1465504454.

${ }^{213}$ See id.

${ }^{214}$ See Rosenburg, supra note 202.

${ }^{215}$ Charlie Savage, Jeff Sessions Dismisses Hawaii as 'an Island in the Pacific,' N.Y. TIMEs (April 20, 2017), https://www.nytimes. com/2017/04/20/us/politics/jeff-sessions-judge-hawaii-pacific-island.html?auth=login-email\&login=email (April 20, 2017).
} 
course, was Hawaii is a U.S. state, and the judge was a duly appointed, highly respected United States district court judge with life tenure under article III of the U.S. Constitution.

Historically, U.S. federal judges have not hesitated to make decisions that were at odds with what the well-known views and philosophy of the presidents who appointed them. ${ }^{216}$ Indeed, presidents endeavor to appoint federal judges who share their philosophy. However, many factors make this goal a limited one. The president nominates federal judges, but they must be confirmed by the Senate. Until recently, sixty out of 100 votes were required to confirm a president's nominee in the U.S. Senate. Even when the president's party has a Senate majority, it will often not amount to a sixty-forty- majority. As a result, again the nominee must be chosen who is not extreme enough to motivate the opposition party to filibuster and block a nomination with seats from forty-one - forty-nine. In addition, life appointments produce at least some judges who change their views over time, becoming less like the president who appointed them. As well, the overriding respect for law and precedent means that lower court judges follow precedents they would disagree with if they had power to change them. And Supreme Court Justices are reluctant to overrule prior Supreme Court precedents, and they do so far less frequently than their own judicial and legal philosophy - and that of the president who appointed them-would seem to indicate. Finally, the U.S. has had a relatively frequent change from one party to the other being in the presidency and control of the Senate. As such, a president's influence is moderated.

There are enough examples to fill a book of federal judges who did not turn out as the president who appointed them might have predicted or wished. Here are but three prominent examples. John Paul Stevens, appointed by Republican President Ford became the senior leader of the liberal wing of the Court. He died recently, giving journalists and others the opportunity to remember the irony:

Societal debates over the rights of gay men and lesbians, the role of race, private property rights, environmental regulation and the separation of church and state also made their way onto the Supreme Court's docket, and Justice Stevens, a low-key Republican from Chicago, was as surprised as anyone to find himself not only taking the liberal side but also becoming its ardent champion. ${ }^{217}$

Earl Warren, former Republic Attorney General and then Governor of California, nominated to the Supreme Court by Republican President Dwight Eisenhower, led the longest sustained liberal period in Supreme Court history, enshrining civil rights, criminal defendants' rights and voting rights for minorities. ${ }^{218}$ All of this was so significantly to the consternation of conservatives that it was not uncommon in the U.S. South to see "Impeach Earl Warren" billboards along highways. ${ }^{219}$

Third, William Brennan, also appointed by Eisenhower, led the liberal wing of the Warren court and continued in his role as the most liberal member of the Court until 1990, ${ }^{220}$ long enough to engage in celebrated judicial opinion scuffles with a new Justice at the time, Antonin Scalia.

In the aftermath of the 2020 election, a striking example emerged of how federal judges' appointments and conduct afterwards normally proceeds. The presiding judge in perhaps the most widely followed of the Trump campaigns' many lawsuits claiming fraud or election mismanagement was Matthew Brann of the United States District Court for the Middle District of Pennsylvania. This civil action prominently featured Rudy Giuliani's return to courtroom work after an absence of nearly thirty years.

\footnotetext{
${ }^{216}$ See Alejandro de le Garza, President Trump's Spat with Chief Justice Roberts Isn't the First Time a President Has Sparred With the Supreme Court, Time (Nov. 22, 2018), https://time.com/5462066/trump-roberts-president-supreme-court-history/.

${ }^{217}$ Linda Greenhouse, Supreme Court Justice John Paul Stevens, Who Led Liberal Wing, Dies at 99, N.Y. TIMES (July 16, 2019), https://www.nytimes.com/2019/07/16/us/john-paul-stevens-dead.html.

${ }^{218}$ See Earl Warren, OYEZ, https://www.oyez.org/justices/earl_warren (last visited Aug 23, 2021).

${ }^{219}$ Newsdesk, Impeach Earl Warren, CHICAGO TRIBUNE (Sept. 24, 2006), https://www.chicagotribune.com/chinews-mtblog2006-09-impeach_earl_warren-story.html.

${ }^{220}$ William J. Brennan Jr., OYEZ, https://www.oyez.org/justices/william_j_brennan_jr (last visited Aug 23, 2021).
} 
Judge Brann was appointed by Barrack Obama, so, according to Donald Trump's attacks on judicial independence, he was sure to rule against the Trump campaign. He did rule against the Trump campaign, in a scathing opinion that demolished the work of the Trump "elite strike force" team of lawyers. Nevertheless, there is much more to the back-story of Judge Brann and his appointment to the federal bench.

Before being appointed, Judge Brann was a long-time Republican Party official in Pennsylvania. He was a conservative Republican, as indicated by his membership in the Federalist Society. The Federalist Society has essentially been the font from which nearly all recommendations to Donald Trump for federal judgeships during his four-year term. Some have reliably said that the Trump administration essentially ceded to the Federalist Society control and management of the filling of federal judgeships with highly conservative judges.

How did it come to pass that Barrack Obama would nominate such a person to the federal bench? ${ }^{221}$ The process was a typical example of normalcy during periods when the White House is in the hands of one party and the Senate is in the hands of the other. This phenomenon is exceedingly common. In normal times, the Senators from a state in which a federal judgeship is open and to be filled make recommendations to the president. These recommendations, while not binding, are honored as long as they are reasonable and not dramatically at odds with the particular president's philosophy.

Judge Brann would arguably be a nomination dramatically at odds with Barrack Obama's philosophy. Yet Obama nominated him. The nomination was recommended by the Republican Senator from Pennsylvania, Pat Toomey. The nomination was paired with another nomination to the same court, this one recommended by the Democratic Senator from Pennsylvania, Bob Casey Jr. The Senate confirmed the paired nominations by unanimous consent. As a result of this obvious compromise, the Republican-controlled Senate got a judge they preferred, Judge Brann, and Barrack Obama got a judge he preferred.

To anyone aware of this compromise and Judge Brann's background, it would sound odd to label him "Obama's judge." 222 However, to an uncritical listener of Trump, it all makes perfect sense: Another Obama judge has issued a harsh, scathing rebuke of Donald Trump's lawyers' assertions of election fraud in Pennsylvania. Indeed, Trump himself tweeted following Judge Brann's ruling: "It's all a continuation of the never ending Witch Hunt, ... Judge Brann, who would not even allow us to present our case or evidence, is a product of Senator Pat 'No Tariffs' Toomey of Pennsylvania, no friend of mine, \& Obama - No wonder." 223 Moreover, Rudy Giuliani, on behalf of the Trump campaign, decried the ruling of the "Obama-appointed judge." 224

Finishing the pattern of federal judges who do not blindly support the president who nominated them, the United States Court of Appeals for the Third Circuit, affirming Judge Brann's ruling, also in harsh tones directed toward the incompetence of the Trump campaign

\footnotetext{
${ }^{221}$ On the topic of liberal versus conservative candidates with membership in the Federalist Society and the American Constitution Society for Law and Policy, see Michael Avery \& Danielle McLaughlin, The Federalist Society: How Conservatives Took the LaW Back from Liberals (2013); Nancy Scherer \& Banks Miller, The Federalist Society's Influence on the Federal Judiciary, 62 POL. Res. Q. 366 (2009).

${ }^{222}$ Michael McGough, Opinion: Don't Jump to Conclusions About an 'Obama Judge' who Ruled Against Trump, L.A. Times (Nov. 24, 2020), https://www.latimes.com/opinion/story/2020-11-24/dont-jump-to-conclusions-about-anobama-judge-who-ruled-againsty-trump.

${ }^{223}$ No longer accessible tweets because Donald Trump was suspended from Twitter. Donald Trump, (@realDonaldTrump), TwITTER https://twitter.com/realDonaldTrump/status/1330374020613758977?ref_src=twsrc\%5Etfw\%7Ctwcamp\%5Etweetembed \%7Ctwterm\%5E1330374263581368320\%7Ctwgr\%5E\%7Ctwcon\%5Es2_\&ref_url=https\%3A\%2F\%2Fthehill.com\%2Fhomenews\% 2F527053-trump-vows-to-appeal-judges-dismissal-of-pennsylvania-election-challenge.

${ }^{224}$ Rudy Giuliani (@RudyGiuliani), TwiTter, (Nov. 21, 2020, 9:07 PM) https://twitter.com/RudyGiuliani/status/ $1330331934745047045 /$ photo/1.
} 
and its lawyers, ${ }^{225}$ was written by a Trump-appointed judge for a three judge panel that also included two judges appointed by George W. Bush. ${ }^{226}$

And in any event, judges have historically lost their connection with the president who appointed them fairly readily. In the U.S. it is anathema to think of a judge belonging to the president who nominated him or her. Trump's tactic of undermining the public's trust in the judiciary has been truly insidious. It works not only on his adherents but on his opponents. ${ }^{227}$ Members of the public who oppose Trump and who are insensitive to the culture and necessity of independent judges now decry decisions favoring Trump as those rendered by Trump's judge. ${ }^{228}$ If it succeeds at changing public view, no change of political power will undo it. If public trust in judges is disqualified, generations will pass before the level of trust can be restored to pre-Trump levels.

\section{F. Comparisons and Concluding Thoughts}

All three forms of judicial independence attacks — vulgar, clumsy, systemic, and insidious - are dangerous and must be met with effective responses. Nevertheless, they differ in significant ways.

Vulgar attacks on judicial independence, when a state actor approaches a judge to apply pressure for a favorable decision, happened in Czechia and Slovakia. ${ }^{229}$ Still, the outcomes in these two countries were very different. What in the Czech Republic appeared eventually as a clumsy attack, leading civil society to support the judiciary, in Slovakia had detrimental effects, leading the public to call for the political power to intervene in the judiciary by enacting constitutional reform. Such attacks might be considered isolated events in a country with stable formal institutions. The outcome for judicial independence depends on the resilience of the institutions. If the attacks happen in an environment where the informal practice clashes with formal institutions, the changes may produce detrimental long-term effects, as in Slovakia after "Threema."

The systemic attacks in Poland and Hungary are more dangerous than the vulgar attacks. The attacks, too, may elicit some public protest, as took place. Nevertheless, faced with a majority or supermajority in parliament, the government has more capacity to stay its course. In Poland, the public response was undoubtedly softened to at least some degree by the public relations attacks engaged in by PiS as it introduced its judicial attack. The systemic attack, especially in Hungary, where a new constitution was adopted, will last until a change of the political winds. Moreover, to be sure, Fidesz has built protections into the election system that will protect it from anything less than a cyclone-force change of political wind. Nevertheless, when the day of political change comes, however long it might take, a better-motivated government will have the power to undo the structural changes.

The most dangerous attacks may be the insidious ones taking place in the U.S., and to some degree in Poland and Hungary based on the anti-judiciary public relations attacks on the hearts and minds of citizens. Public trust is the foundation of judicial power and its key underlying attributes. An attack that successfully undermines public trust in the judiciary will deliver the most far-reaching damage. By contrast, the U.S. experience with judicial independence runs deep into the culture and is protected by an elaborate system of checks and balances among the three branches.

\footnotetext{
${ }^{225}$ Alan Feuer, In Harsh Rebuke, Appeals Court Rejects Trump’s Election Challenge in Pennsylvania, N.Y. TIMEs (Nov. 27, 2020), https://www.nytimes.com/2020/11/27/us/politics/trump-pennsylvania-appeals-court.html.

${ }^{226}$ Read the Third Circuit Court of Appeals Ruling in Pennsylvania Election, WASH. Post (Nov. 27, 2020), https://www. washingtonpost.com/context/read-the-third-circuit-court-of-appeals-ruling-in-pennsylvania-election/e2bfd645-efb54862-8680-ce92c9ccf6e2/?itid=lk_interstitial_manual_6.

${ }^{227}$ Michael J. Nelson \& James L. Gibson, Has Trump Trumped the Courts, 93 N.Y.U. L. Rev. OnLINE 32, 34 (2018).

${ }^{228}$ Richard Wolf, Biden's Influence on Federal Judiciary May be Limited Despite Liberals' Talk of 'Court-Packing', USA TODAY (Dec. 20, 2021), https://www.usatoday.com/story/news/politics/2020/12/20/trumps-impact-federal-judiciary-mayhard-biden-reverse/6541264002/.

${ }^{229}$ The situation in Slovakia is elaborated in detail in Peter Čuroš Panopticon of the Slovak Judiciary, in this Special Issue.
} 
To be clear, not all government-proposed restrictions on the judicial branch are attacks on judicial independence. Judicial independence is meant to empower judges to act justly. It prevents the government from placing its thumb on one side of the scales of justice, from interfering with a judge's impartial decision of a case according to the law and the facts. However, judicial independence is not permission for judges to engage in wrongdoing. It is not a defense against the requirement of making transparent decisions. It is not an impenetrable force field that prevents judges from being held accountable for the quality and integrity of their judicial work. The parliamentary majority may limit judicial autonomy without an intention to meddle in outcomes of decisionmaking. Still, the motives and effectiveness of the political actors in our analysis were to capture control over judicial decisions in matters of importance to the government-in-power, and therefore we consider them as attacks.

Cite this article: Moliterno JE, Čuroš P (2021). Recent Attacks on Judicial Independence: The Vulgar, the Systemic, and the Insidious. German Law Journal 22, 1159-1191. https://doi.org/10.1017/glj.2021.63 